Check for updates

Cite this: Chem. Sci., 2017, 8, 7424

\title{
Comparisons of lanthanide/actinide +2 ions in a tris(aryloxide)arene coordination environment $\uparrow$
}

\author{
Megan E. Fieser, (DD a Chad T. Palumbo, (D) ${ }^{a}$ Henry S. La Pierre, (DD ${ }^{b}$ \\ Dominik P. Halter, (DD ${ }^{\mathrm{b}}$ Vamsee K. Voora, (DD) a Joseph W. Ziller, (D) ${ }^{a}$ Filipp Furche, (D) *a \\ Karsten Meyer (D) ${ }^{* b}$ and William J. Evans (D)*a
}

A new series of $\mathrm{Ln}^{3+}$ and $\mathrm{Ln}^{2+}$ complexes has been synthesized using the tris(aryloxide)arene ligand system, $\left(\left({ }^{\mathrm{Ad}, \mathrm{Me}} \mathrm{ArO}\right)_{3} \mathrm{mes}\right)^{3-}$, recently used to isolate a complex of $U^{2+}$. The triphenol precursor, $\left({ }^{\mathrm{Ad}, \mathrm{Me}} \mathrm{ArOH}\right)_{3} \mathrm{mes}$, reacts with the $\mathrm{Ln}^{3+}$ amides, $\mathrm{Ln}\left(\mathrm{NR}_{2}\right)_{3}(\mathrm{R}=\mathrm{SiMe})_{3}$, to form a series of $\left[\left(\left({ }^{\mathrm{Ad}, M e} \mathrm{ArO}\right)_{3}\right.\right.$ mes $\left.) \mathrm{Ln}\right]$ complexes, 1- $\mathrm{Ln}$. Crystallographic characterization was achieved for $\mathrm{Ln}=\mathrm{Nd}$, Gd, Dy, and Er. The complexes 1-Ln can be reduced with potassium graphite in the presence of 2.2.2-cryptand (crypt) to form highly absorbing solutions with properties consistent with $\mathrm{Ln}^{2+}$ complexes, [K(crypt)][(( $\left.\left.\left.{ }^{\mathrm{Ad}, \mathrm{Me}} \mathrm{ArO}\right)_{3} \mathrm{mes}\right) \mathrm{Ln}\right], 2-\mathrm{Ln}$. The synthesis of the $\mathrm{Nd}^{2+}$ complex $[\mathrm{K}(\mathrm{crypt})]\left[\left(\left(^{\mathrm{Ad}, \mathrm{Me}} \mathrm{ArO}\right)_{3} \mathrm{mes}\right) \mathrm{Nd}\right], 2-\mathrm{Nd}$, was unambiguously confirmed by $\mathrm{X}$-ray crystallography. In the case of the other lanthanides, crystals were found to contain mixtures of 2-Ln cocrystallized with either a $\mathrm{Ln}^{3+}$ hydride complex, [K(crypt)][(( $\left.\left.\left.{ }^{\mathrm{Ad}, \mathrm{Me}} \mathrm{ArO}\right)_{3} \mathrm{mes}\right) \mathrm{LnH}\right], 3-\mathrm{Ln}$, for $\mathrm{Ln}=\mathrm{Gd}$, Dy, and Er, or a hydroxide complex, [K(crypt)][(( $\left.\left.\left(^{\mathrm{Ad}, \mathrm{Me} A r O}\right)_{3} \mathrm{mes}\right) \mathrm{Ln}(\mathrm{OH})\right], 4-\mathrm{Ln}$, for $\mathrm{Ln}=\mathrm{Dy}$. A Dy ${ }^{2+}$ complex with 18crown- 6 as the potassium chelator, $\left.\left[\mathrm{K}(18-\mathrm{crown}-6)(\mathrm{THF})_{2}\right]\left[\left({ }^{\mathrm{Ad}, \mathrm{Me}} \mathrm{ArO}\right)_{3} \mathrm{mes}\right) \mathrm{Dy}\right], 5-\mathrm{Dy}$, was isolated as a cocrystallized mixture with the $\mathrm{Dy}^{3+}$ hydride complex, [K(18-crown-6)(THF) $\left.\left.{ }_{2}\right]\left[\left({ }^{(\mathrm{Ad}, \mathrm{Me}} \mathrm{ArO}\right)_{3} \mathrm{mes}\right) \mathrm{DyH}\right], 6-\mathrm{Dy}$. Structural comparisons of $1-\mathrm{Ln}$ and 2 - $\mathrm{Ln}$ are presented with respect to their uranium analogs and correlated with density functional theory calculations on their electronic structures.

Received 23rd May 2017

Accepted 6th September 2017

DOI: $10.1039 /$ c7sc02337e

rsc.li/chemical-science ions were consistent with reduction of the $4 \mathrm{f}^{n} \mathrm{Ln}^{3+}$ precursors to form $4 \mathrm{f}^{n} 5 \mathrm{~d}^{1}$ ions rather than the traditional $4 \mathrm{f}^{n+1}$ ions, a result explained by density functional theory (DFT) calculations..$^{3-5}$

To enable a direct comparison of the new $4 \mathrm{f}^{n} 5 \mathrm{~d}^{1}$ ions ( $\mathrm{La}, \mathrm{Ce}$, $\mathrm{Pr}, \mathrm{Gd}, \mathrm{Tb}, \mathrm{Dy}, \mathrm{Ho}, \mathrm{Er}$, and Lu) with the traditional $4 \mathrm{f}^{n} 5 \mathrm{~d}^{1}$ ions $(\mathrm{Eu}, \mathrm{Yb}, \mathrm{Sm}, \mathrm{Tm}, \mathrm{Nd}, \mathrm{Dy})$ in a single coordination environment, $[\mathrm{K}(\mathrm{crypt})]\left[\mathrm{Cp}_{3}^{\prime} \mathrm{Ln}\right]$ complexes were synthesized for the entire lanthanide series (except Pm, which was not studied due to its radioactivity), eqn (1). This revealed that in the $\left(\mathrm{Cp}_{3}^{\prime}\right)^{3-}$ coordination environment, $\mathrm{Nd}^{2+}$ and $\mathrm{Dy}^{2+}$ have properties consistent with $4 \mathrm{f}^{n} 5 \mathrm{~d}^{1}$ ground states, instead of the $4 \mathrm{f}^{n+1}$ ground state in previously identified $\mathrm{Nd}^{2+}$ and $\mathrm{Dy}^{2+}$ complexes. These ions therefore are not traditional $4 \mathrm{f}^{n+1} \mathrm{Ln}^{2+}$ ions, but are configurational crossover ions that can have a variable electronic ground state depending on the ligand environment. This was an unusual result in molecular lanthanide chemistry, given that the limited radial extension of the $4 \mathrm{f}$ orbitals generally precludes ligand influences on the electronic configuration. The $[\mathrm{K}(\mathrm{crypt})]\left[\mathrm{Cp}^{\prime}{ }_{3} \mathrm{Ln}\right]$ results suggest that there are now three classes of $\mathrm{Ln}^{2+}$ ions: traditional $4 \mathrm{f}^{\mathrm{n}+1}$ ions, $\mathrm{Ln}=\mathrm{Eu}, \mathrm{Yb}, \mathrm{Sm}$, and $\mathrm{Tm}$, the new $4 \mathrm{f}^{n} 5 \mathrm{~d}^{1}$ ions, $\mathrm{Ln}=\mathrm{La}, \mathrm{Ce}, \mathrm{Pr}, \mathrm{Gd}, \mathrm{Tb}, \mathrm{Ho}$, Er, and Lu, and the configurational crossover ions, $\mathrm{Ln}=\mathrm{Nd}$ and Dy, which can have either $4 \mathrm{f}^{n+1}$ or $4 \mathrm{f}^{n} 5 \mathrm{~d}^{1}$ configurations depending on the coordination environment. Since these groupings arise only from the $\left(\mathrm{Cp}_{3}^{\prime}{ }_{3}\right)^{3-}$ ligand set, it was desirable to find other ligand environments for comparison. 

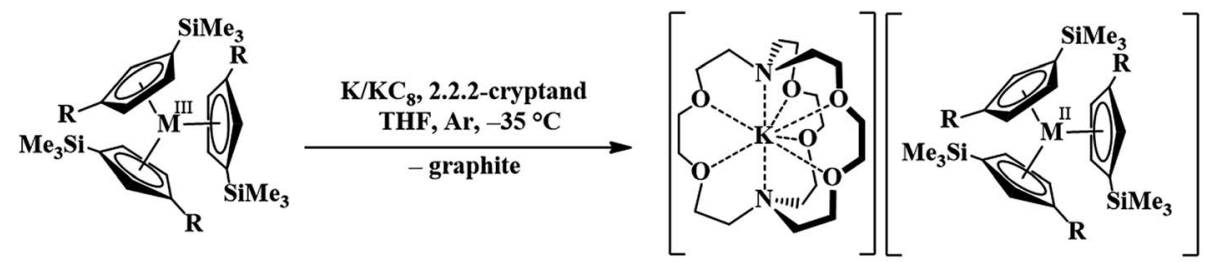

$\mathbf{R}=\mathrm{SiMe}_{3} ; \mathbf{M}=\mathbf{L a}, \mathrm{Th}, \mathrm{U}, \mathrm{Pu}$

$\mathrm{R}=\mathrm{H} ; \mathrm{M}=\mathrm{Y}, \mathrm{La}, \mathrm{Ce}, \mathrm{Pr}, \mathrm{Nd}, \mathrm{Sm}, \mathrm{Gd}, \mathrm{Tb}, \mathrm{Dy}, \mathrm{Ho}, \mathrm{Er}, \mathrm{Tm}, \mathrm{Lu}, \mathrm{U}$

The first crystallographically-characterized $\mathrm{U}^{2+}$ complex, $[\mathrm{K}(\mathrm{crypt})]\left[\mathrm{Cp}_{3}^{\prime} \mathrm{U}\right]$, was also obtained via eqn (1). ${ }^{6}$ Analyses of this complex by X-ray crystallography, UV-visible spectroscopy, and DFT were consistent with a quintet $5 \mathrm{f}^{3} 6 \mathrm{~d}^{1}$ ground state for $\mathrm{U}^{2+}$ in this coordination environment and the complex displayed properties similar to those of the complexes with $4 \mathrm{f}^{n} 5 \mathrm{~d}^{1} \mathrm{Ln}^{2+}$ ions. Shortly thereafter, a second $\mathrm{U}^{2+}$ complex was reported: the tris(aryloxide)arene $\mathrm{U}^{3+}$ complex, $\left[\left(\left({ }^{\mathrm{Ad}, \mathrm{Me}} \mathrm{ArO}\right){ }_{3} \mathrm{mes}\right) \mathrm{U}\right], \mathbf{1 - U}$, could be reduced to the $\mathrm{U}^{2+}$ complex, $[\mathrm{K}(\mathrm{crypt})]\left[\left(\left({ }^{\mathrm{Ad}, \mathrm{Me}} \mathrm{ArO}\right)_{3} \mathrm{mes}\right)\right.$ U], 2-U, eqn (2). ${ }^{11,12}$ a comparative study with both ligand environments, $\left[\left({ }^{\mathrm{Ad}, \mathrm{Me}} \mathrm{ArO}\right)_{3} \mathrm{mes}\right]^{3-}$ and $\left[\mathrm{Cp}^{\prime}\right]^{3-}$, may shed light on the nature of configurational crossover. To explore this possibility, the synthesis of complexes of new $\mathrm{Ln}^{2+}$ ions with the $\left[\left({ }^{\mathrm{Ad}, \mathrm{Me}} \mathrm{ArO}\right)_{3^{-}}\right.$ mes] $]^{3-}$ ligand was pursued. Numerous $\mathrm{Ln}^{3+}$ aryloxide complexes have been previously reported in the literature. ${ }^{13-34}$ The synthesis and structural characterization of $\mathrm{Ln}^{3+}$ complexes of the $\left[\left({ }^{\mathrm{Ad}, \mathrm{Me}} \mathrm{ArO}\right)_{3} \mathrm{mes}\right]^{3-}$ ligand are reported here as well as their reduction chemistry. This has led to highly reactive $\mathrm{Ln}^{2+}$ complexes that often co-crystallize either with $\mathrm{Ln}^{3+}$ hydride or
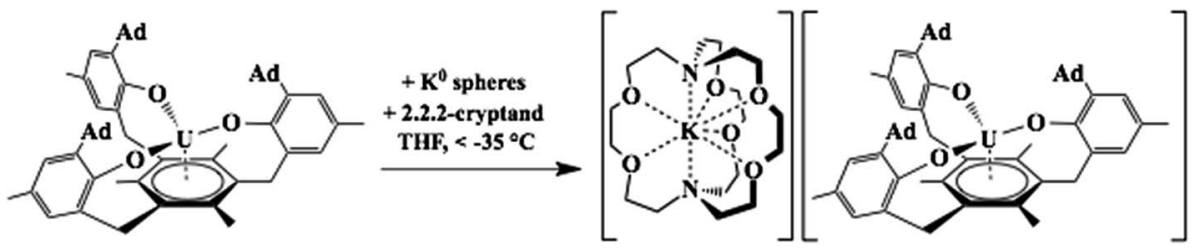

Previous DFT studies on 1-U revealed two SOMOs with $\delta$ backbonding interactions with f orbitals and one SOMO containing a non-bonding uranium 5 f electron; $2-\mathbf{U}$ is similar except there are two non-bonding uranium $5 \mathrm{f}$ electrons. Hence, computational analysis of 2-U was consistent with an $S=2,5 \mathrm{f}^{4}$ ground state for $\mathrm{U}^{2+}$. Experimental support for the predicted $5 \mathrm{f}^{4}$ electronic ground state was obtained by X-band EPR spectroscopy as well as solidstate and solution-phase magnetochemical studies.

The isolation of two $\mathrm{U}^{2+}$ complexes with different ground state configurations due to their respective coordination environments indicates that uranium should likewise fit into the configurational crossover class of +2 ions described above for the lanthanides. Since uranium is a congener of neodymium, the suggested classification has some periodic consistency. These results also suggested that in the case of $\mathrm{Ln}^{2+}$ ions,
$\mathrm{Ln}^{3+}$ hydroxide byproducts. DFT analysis is used to evaluate the electronic structures and make comparisons with uranium.

\section{Results and discussion}

\section{Synthesis and structure of the $\mathrm{Ln}^{3+}$ complexes} $\left[\left(\left({ }^{\text {Ad,Me }} \mathrm{ArO}\right)_{3} \mathrm{mes}\right) \mathrm{Ln}\right]$, 1-Ln

The trivalent complexes, [(( $\left.\left.\left.{ }^{\mathrm{Ad}, \mathrm{Me}} \mathrm{ArO}\right){ }_{3} \mathrm{mes}\right) \mathrm{Ln}\right], \mathbf{1}-\mathbf{L n}(\mathrm{Ln}=\mathrm{Nd}, \mathrm{Gd}$, Dy, and Er), were synthesized by protonolysis of $\left[\mathrm{Ln}\left(\mathrm{N}\left(\mathrm{SiMe}_{3}\right)_{2}\right)_{3}\right]$ with the tris(phenol), $\left({ }^{\mathrm{Ad}, \mathrm{Me}} \mathrm{ArOH}\right)_{3}$ mes, eqn (3), and identified by X-ray crystallography, Fig. 1. The Gd, Dy, and Er complexes crystallize in the $P 2_{1} / c$ space group and are isomorphous. 1-Nd also crystallizes in $P 2_{1} / c$ and is similar in structure, but is not isomorphous with the other 1-Ln compounds (see ESI $\dagger$ for details). In comparison, 1-U crystallizes in $P \overline{1}$.
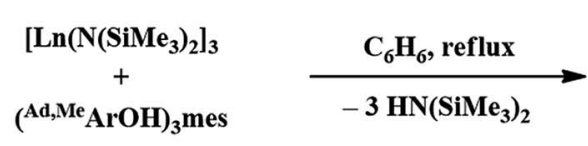

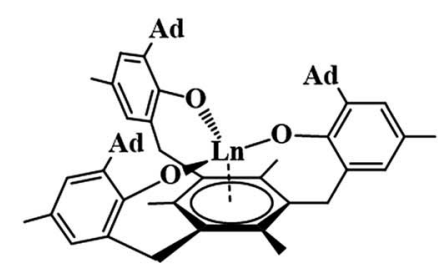




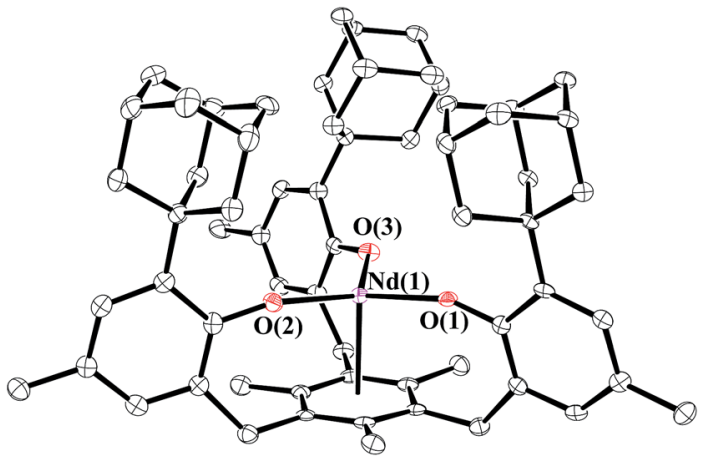

Fig. 1 Molecular structure of [(( $\left.\left.\left.{ }^{\mathrm{Ad}, \mathrm{Me}} \mathrm{ArO}\right)_{3} \mathrm{mes}\right) \mathrm{Nd}\right], 1-\mathrm{Nd}$, with thermal ellipsoids drawn at the $50 \%$ probability level. Hydrogen atoms are omitted for clarity.

The structural parameters of 1-Ln follow a regular trend based on the metal ionic radii, Table 1 . Hence, the $\mathrm{M}-\mathrm{O}$ distances and the $\mathbf{M}$-(arene ring centroid) distances decrease regularly from $\mathrm{Nd}$ to $\mathrm{Er}$ as the size of the $\mathrm{Ln}^{3+}$ ion decreases. The Ln-O distances for 1-Ln fall in the range of reported $\mathrm{Ln}$ $\mathrm{O}$ (aryloxide) distances for complexes such as $\left[\mathrm{Ln}\left(\mathrm{OC}_{6} \mathrm{H}_{3}{ }^{t} \mathrm{Bu}_{2}{ }^{-}\right.\right.$ $\left.2,6)_{3}(\mathrm{THF})_{3}\right] \quad\left(\mathrm{Ln}=\mathrm{Nd},{ }^{35} \quad \mathrm{Gd},{ }^{36} \mathrm{Er}^{37}\right), \quad\left[\mathrm{Dy}\left(\mathrm{OC}_{6} \mathrm{H}_{3}{ }^{i} \mathrm{Pr}_{2^{-}}\right.\right.$ $\left.2,6)_{3}(\mathrm{DME})_{2}\right],{ }^{38}$ as well as other rare earth aryloxide complexes. ${ }^{\mathbf{1 3 - 3 4}}$ In contrast, the $\mathbf{M}$-(arene centroid) distances of 1-Ln are significantly shorter than those reported for $\mathrm{Ln}^{3+}$ arene complexes such as (arene) $\operatorname{Ln}\left[(\mu-\mathrm{Cl})_{2} \mathrm{AlCl}_{2}\right]_{3} \cdot{ }^{39-50}$ For example, $\left(\eta^{6}-1,3,5-\mathrm{C}_{6} \mathrm{H}_{3} \mathrm{Me}_{3}\right) \mathrm{Nd}\left[\left(\mathrm{AlCl}_{4}\right)_{3}\right]^{42}$ has a $2.566 \AA$ Ln-(arene centroid) distance compared to $2.489 \AA$ for 1 -Nd.

Table 1 also shows that the distances for 1-U do not match those of 1-Ln in terms of radial size and metal-ligand distance. Both the $\mathrm{U}-\mathrm{O}$ and $\mathrm{U}$-(arene centroid) distances of the $\mathrm{U}^{3+}$ complex are shorter than those of the lanthanides. This difference can be rationalized by greater orbital overlap between the ligand orbitals and the $5 \mathrm{f} v s$. the $4 \mathrm{f}$ metal orbitals. Regardless of these differences, the average $\mathrm{C}-\mathrm{C}$ bond distances in the arene ring are within error of those of the free ligand, $\left({ }^{\mathrm{Ad}, \mathrm{Me}} \mathrm{ArOH}\right)_{3^{-}}$ mes, whose structure was determined as part of this study (see ESI $\dagger$ ). Thus there is no evidence of reduction of the arene ring.

\section{Reduction reactions}

Reduction of each 1-Ln complex was carried out in 1:1 THF/ $\mathrm{C}_{6} \mathrm{H}_{6}$ with potassium graphite $\left(\mathrm{KC}_{8}\right)$ in the presence of 2.2.2cryptand (crypt). In each case, highly absorbing red-colored solutions were obtained that were reminiscent of the

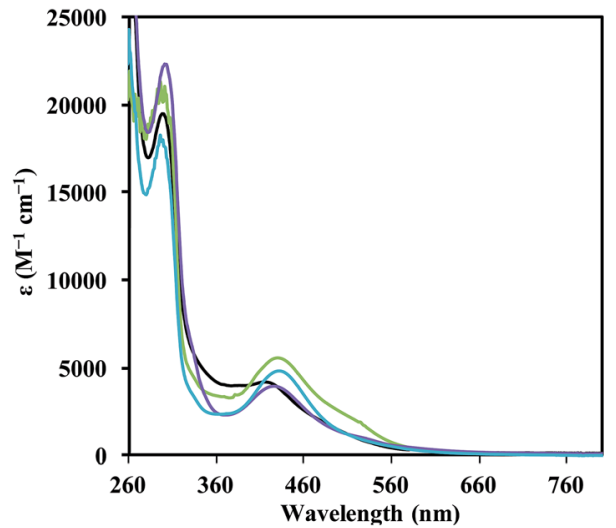

Fig. 2 UV-visible spectra of [K(chelate)][(( $\left.\left.\left.{ }^{\mathrm{Ad}, \mathrm{Me}} \mathrm{ArO}\right){ }_{3} \mathrm{mes}\right) \mathrm{Ln}\right]$ with $\mathrm{Ln}=$ $\mathrm{Nd}$ (black), Gd (purple), Er (green), and Dy (blue), recorded in THF at $298 \mathrm{~K}$. The solutions were generated from crystals of 2-Nd, 2-Ln/3-Ln $(\mathrm{Ln}=\mathrm{Gd}, \mathrm{Er})$, and 5-Dy/6-Dy. Extinction coefficients, $\varepsilon$, for 2-Ln (Nd, $\mathrm{Gd}, \mathrm{Er}$ ) and 5-Dy were calculated using concentrations of $\mathrm{Ln}^{2+}$ estimated using Ln(1) occupancy from the crystallographic data.

intensely-colored solutions produced in the reductions of the $\mathrm{Cp}^{\prime}{ }_{3} \mathrm{Ln}$ complexes in eqn (1). The UV-visible electronic absorption spectra of these dark solutions, as shown in Fig. 2, differ greatly from the line-like spectra typical of $\mathrm{Ln}^{3+}$ complexes (see 1-Nd, Fig. S11 $\dagger$ ). Each complex has a strong broad absorption band in the visible region with the following maxima $\left(\lambda_{\max }, \varepsilon\right)$ : Nd (416 nm, $4200 \mathrm{M}^{-1} \mathrm{~cm}^{-1}$ ), Gd (426 nm, $4000 \mathrm{M}^{-1} \mathrm{~cm}^{-1}$ ), Dy (431 nm, $4900 \mathrm{M}^{-1} \mathrm{~cm}^{-1}$ ), and $\operatorname{Er}\left(430 \mathrm{~nm}, 5600 \mathrm{M}^{-1} \mathrm{~cm}^{-1}\right)$. The absorption energies and extinction coefficients of $\mathbf{2}$-Ln are similar to those reported for the $[\mathrm{K}(\mathrm{crypt})]\left[\mathrm{Cp}^{\prime}{ }_{3} \mathrm{Ln}\right]$ complexes $\left(\lambda_{\max }, \varepsilon\right): \mathrm{Nd}\left(420 \mathrm{~nm}, 4700 \mathrm{M}^{-1} \mathrm{~cm}^{-1}\right)$, Gd $(430 \mathrm{~nm}$, $\left.4400 \mathrm{M}^{-1} \mathrm{~cm}^{-1}\right)$, Dy (483 nm, $\left.3400 \mathrm{M}^{-1} \mathrm{~cm}^{-1}\right)$, and $\operatorname{Er}(502 \mathrm{~nm}$, $\left.4000 \mathrm{M}^{-1} \mathrm{~cm}^{-1}\right)$. Although all of these absorption bands for 2Ln are broad, they appear to follow a trend in which the absorption energy decreases with increasing atomic number. Single crystals of the reduction products were obtained for $\mathrm{Ln}=$ Nd, Gd, Er, and Dy and are described below.

\section{Neodymium}

Reduction of 1-Nd produced a new example of a $\mathrm{Nd}^{2+}$ complex, $[\mathrm{K}(\mathrm{crypt})]\left[\left(\left({ }^{\mathrm{Ad}, \mathrm{Me}} \mathrm{ArO}\right)_{3} \mathrm{mes}\right) \mathrm{Nd}\right]$, 2-Nd, eqn (4), which was confirmed by single-crystal X-ray diffraction, Fig. 3. Crystals of 2-Nd form in space group $P 2_{1} / c$ and are isomorphous with crystals of the $\mathrm{U}^{2+}$ complex, [K(crypt)][(( $\left.{ }^{\mathrm{Ad}, \mathrm{Me}} \mathrm{ArO}\right)_{3}$ mes $\left.) \mathrm{U}\right]$, 2-U (see ESI $\left.\dagger\right)$.

Table 1 Selected bond lengths $(\AA \AA)$ and angles $\left(^{\circ}\right)$ of 1-Ln and 1-U listed in order of decreasing ionic radius

\begin{tabular}{lllllll}
\hline Metal & Six coordinate ionic radius & & M-O range & M-O avg & M-C $_{6}$ (ring centroid) & M out of plane $^{b}$ C $_{6}$ torsion angle \\
\hline U & 1.025 & $2.158(2)-2.178(2)$ & $2.17(1)$ & 2.35 & $0.475(2)$ & 6.8 \\
Nd & 0.983 & $2.172(3)-2.200(2)$ & $2.19(1)$ & 2.489 & 0.268 & 5.6 \\
Gd & 0.938 & $2.132(2)-2.134(2)$ & $2.133(1)$ & 2.413 & 0.416 & 0.443 \\
Dy & 0.912 & $2.093(3)-2.095(3)$ & $2.094(1)$ & 2.368 & 8.1 \\
Er & 0.89 & $2.078(2)-2.081(2)$ & $2.079(1)$ & 2.336 & 0.477
\end{tabular}

${ }^{a}$ From Shannon. ${ }^{51}{ }^{b}$ Distance of $\mathrm{M}$ from the plane defined by the three $\mathrm{O}$ atoms of the $\left(\left({ }^{\mathrm{Ad}, \mathrm{Me}} \mathrm{ArO}\right){ }_{3} \mathrm{mes}\right){ }^{3-}$ ligand. ${ }^{c}$ The largest dihedral angle between adjacent three-carbon planes in the mesitylene ring. 

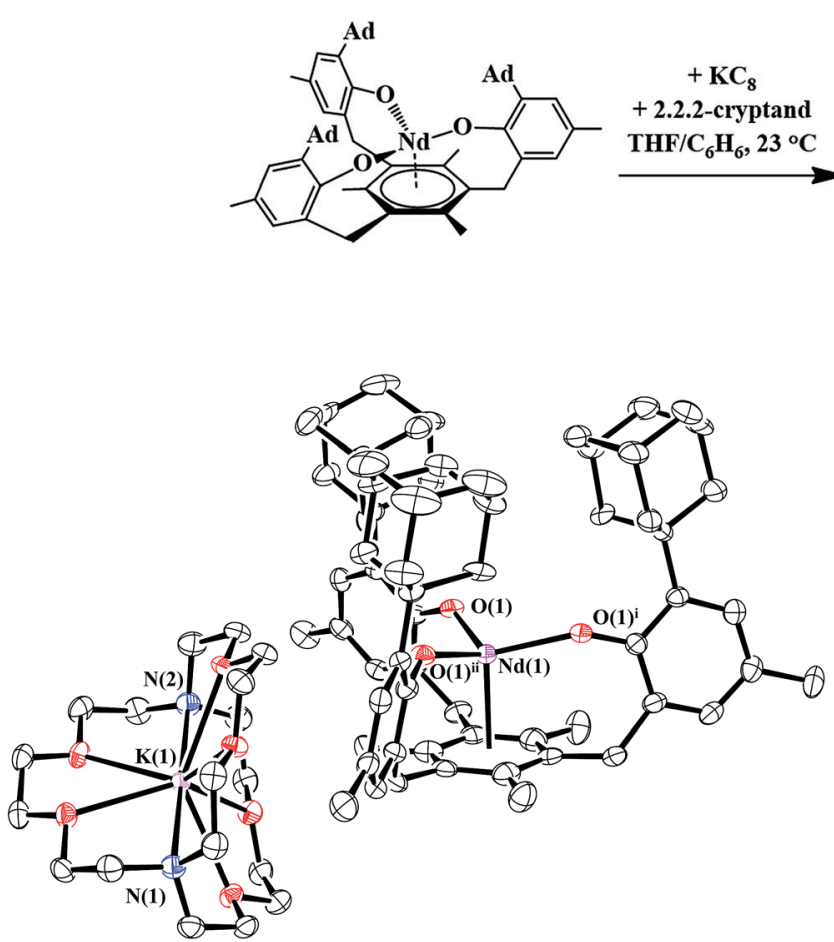

Fig. 3 Molecular structure of [K(crypt)][(( $\left.\left.\left.{ }^{\mathrm{Ad}, \mathrm{Me}} \mathrm{ArO}\right)_{3} \mathrm{mes}\right) \mathrm{Nd}\right], 2-\mathrm{Nd}$ drawn at the $50 \%$ probability level. Hydrogen atoms are omitted for clarity.

\section{Gadolinium and erbium}

Reductions of 1-Gd and 1-Er, performed in a manner analogous to that of eqn (4), produced dark red single crystals suitable for $\mathrm{X}$-ray diffraction that appeared to be isomorphous with 2-Nd (see ESI $\dagger$ ). However, the crystallographic data were best modeled by a mixture of two complexes: the divalent [K(crypt)] $\left[\left(\left({ }^{\mathrm{Ad}, \mathrm{Me}} \mathrm{ArO}\right)_{3} \mathrm{mes}\right) \mathrm{Ln}\right], \mathbf{2 - L n}$, and the trivalent hydride, [K(crypt)] $\left[\left(\left({ }^{\mathrm{Ad}, \mathrm{Me}} \mathrm{ArO}\right)_{3} \mathrm{mes}\right) \mathrm{LnH}\right], 3-\mathbf{L n}$, in a $65: 35$ ratio for $\mathrm{Gd}$ and a 55 : 45 ratio for Er, eqn (5), Fig. 4. The metal centers in both 2Ln and 3-Ln lie on a three-fold axis with the same ligand environment, in which $\operatorname{Ln}(1)$ represents the metal center for 2-Ln and $\operatorname{Ln}(2)$ represents the metal center for $3-\mathbf{L n}$. Consistent with the presence of a hydride ligand, the reaction of 2-Er/3-Er with $\mathrm{CCl}_{4}$ produced chloroform. ${ }^{52}$

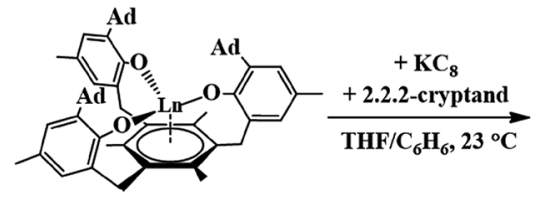

1-Ln

Ln $=$ Gd; $x=0.65, y=0.35$ Ln $=$ Dy; $x=0.63, y=0.37$ Ln = Er; $x=0.55, y=0.45$

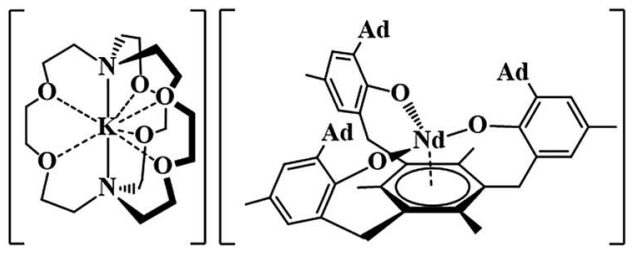

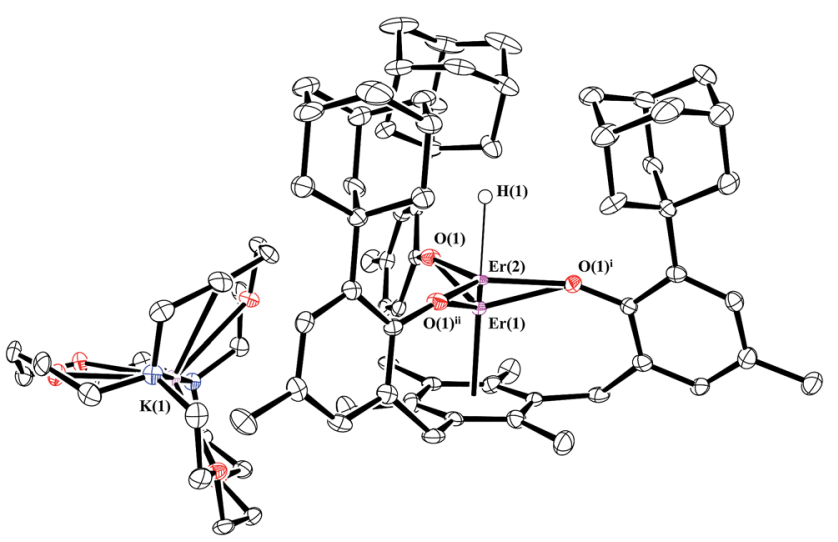

Fig. 4 Molecular structure of [K(crypt)][(( $\left.\left.\left.{ }^{\mathrm{Ad}, \mathrm{Me}} \mathrm{ArO}\right)_{3} \mathrm{mes}\right) \mathrm{Er}\right], 2-\mathrm{Er}$, and [K(crypt)][(( $\left.\left.\left.{ }^{\mathrm{Ad}, \mathrm{Me}} \mathrm{ArO}\right)_{3} \mathrm{mes}\right) \mathrm{ErH}\right], 3-\mathrm{Er}$, which co-crystallize in an approximate $55: 45$ ratio. Thermal ellipsoids are drawn at the 50\% probability level and hydrogen atoms, except $\mathrm{H}(1)$, are omitted for clarity. $\operatorname{Er}(1)$ is the metal position in 2-Er and $\operatorname{Er}(2)$ is the metal position in 3-Er.

Single crystals of 2-Gd/3-Gd dissolved in THF display a single isotropic signal at $g_{\text {iso }}=1.990$ in the room temperature X-band EPR spectrum, Fig. 5a. This is similar to the X-band EPR spectra of the crystallographically-characterized $\mathrm{Gd}^{2+}$ complexes, ${ }^{4,53}$ $[\mathrm{K}(\mathrm{crypt})]\left[\mathrm{Cp}_{3}{ }_{3} \mathrm{Gd}\right]$ and $[\mathrm{K}(\mathrm{crypt})]\left[\mathrm{Cp}^{\prime \prime}{ }_{2} \mathrm{CpGd}\right]\left(\mathrm{Cp}=\mathrm{C}_{5} \mathrm{H}_{5}\right)$, which also show isotropic signals at $g_{\text {iso }}=1.99$. A $4 \mathrm{f}^{7} 5 \mathrm{~d}^{1}$ electron configuration has been proposed for those cyclopentadienyl complexes. Thus, the EPR spectrum of $\mathbf{2 - G d}$ is consistent with a $4 \mathrm{f}^{7} 5 \mathrm{~d}^{1}$ electron configuration for $\mathrm{Gd}^{2+}$ in the $\left(\left({ }^{\mathrm{Ad}, \mathrm{Me}} \mathrm{ArO}\right)_{3^{-}}\right.$ mes) $)^{3-}$ ligand coordination, since it is unlikely that an EPR spectrum of a $4 \mathrm{f}^{8} \mathrm{Gd}^{2+}$ complex would be observable under these conditions. Since a $4 \mathrm{f}^{7} / 4 \mathrm{f}^{8}$ reduction eliminates a halffilled shell, whereas an $4 \mathrm{f}^{7}$ to a $4 \mathrm{f}^{7} 5 \mathrm{~d}^{1}$ reduction does not, the

$\mathbf{x}$
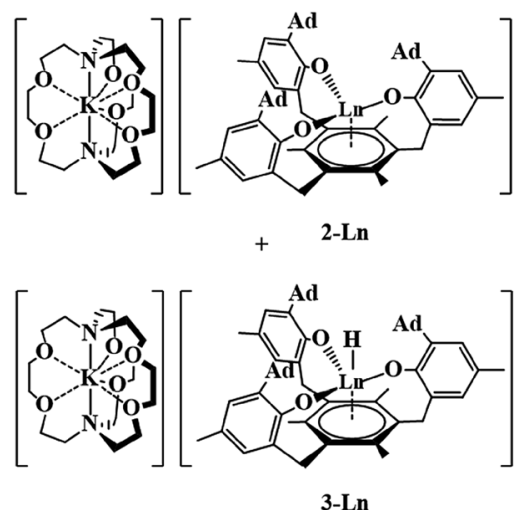


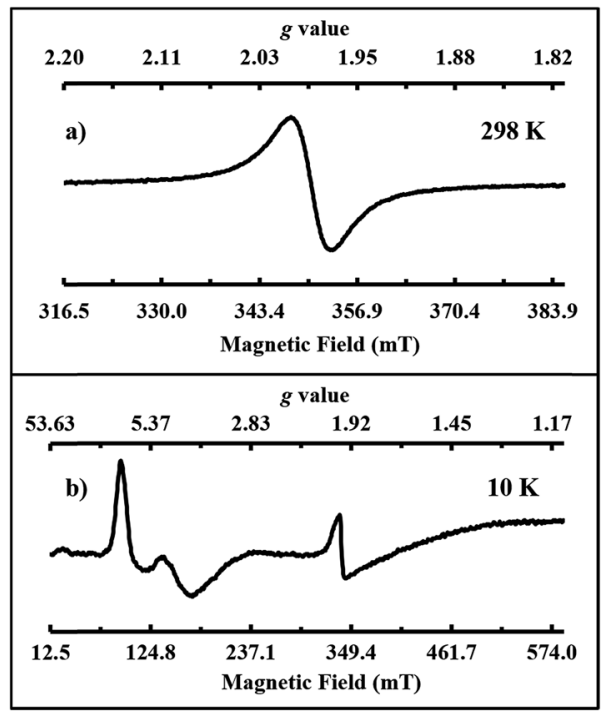

Fig. 5 Experimental X-band EPR spectra of single crystals of 2-Gd/3Gd dissolved in THF (1 mM) at (a) $298 \mathrm{~K}$ (mode: perpendicular; $g_{\text {iso }}=$ $1.990 ; \nu=9.762 \mathrm{GHz} ; P=0.0203 \mathrm{~mW}$; modulation amplitude $=0.902$ $\mathrm{mT}$ ) and (b) $10 \mathrm{~K}$ (mode: parallel; $g_{1}=7.349, g_{2}=4.786, g_{3}=1.977 ; \nu=$ $9.383 \mathrm{GHz} ; P=2.026 \mathrm{~mW}$; modulation amplitude $=1.002 \mathrm{mT}$ ).

latter process would be favored in this regard. Elimination of the half-filled shell is why the calculated redox potential for a $4 \mathrm{f}^{7} / 4 \mathrm{f}^{8}$ process is so high, $-3.9 \mathrm{~V}$ vs. SHE, ${ }^{54}$ whereas the observed gadolinium reduction must occur at potentials less negative than $-2.9 \mathrm{~V}$ vs. SHE. The X-band EPR spectrum recorded in frozen THF solution at $10 \mathrm{~K}$, shown in Fig. 5b, is further consistent with the presence of a $4 \mathrm{f}^{7} 5 \mathrm{~d}^{1} \mathrm{Gd}^{2+}$ ion. Both the $\mathrm{Gd}^{3+}$ and $\mathrm{Gd}^{2+}$ species of the co-crystallized sample of 2-Gd and 3-Gd can be observed by EPR spectroscopy according to our simulations (see ESI $\dagger$ ). The almost axial spectrum of 2-Gd was simulated with $g$ values at $g_{1}=7.02, g_{2}=6.85$, and $g_{3}=3.97$.

Although co-crystallization of $\mathrm{Ln}^{3+}$ hydrides with the $\mathrm{Ln}^{2+}$ complexes complicates the structural analysis (see below), it does suggest that the $\left(\left({ }^{\mathrm{Ad}, \mathrm{Me}} \mathrm{ArO}\right)_{3} \mathrm{mes}\right)^{3-}$ ligand set can enhance the bond activation reactivity of these $\mathrm{Ln}^{2+}$ ions. $\mathrm{C}-\mathrm{H}$ bond activation previously has been observed with the $\mathrm{Nd}^{2+}$ complex, $\left[\left(\mathrm{C}_{5} \mathrm{H}_{2}{ }^{t} \mathrm{Bu}_{3}\right)_{2} \mathrm{Nd}(\mu\right.$-I) $\mathrm{K}(18$-crown-6)], which forms $\left[\left(\mathrm{C}_{5} \mathrm{H}_{2}{ }^{t} \mathrm{Bu}_{3}\right)\left(\mathrm{C}_{5} \mathrm{H}_{2}{ }^{t} \mathrm{Bu}_{2} \mathrm{CMe}_{2} \mathrm{CH}_{2}-\eta^{5}: \kappa^{1}\right) \mathrm{Nd}(\mu-\mathrm{I}) \mathrm{K}\left(18\right.\right.$-crown-6)]. ${ }^{55}$ This was also found in attempts to form indenyl $\mathrm{Ln}^{2+}$ complexes, which led to the indenyl dianion, $\left(\mathrm{C}_{9} \mathrm{H}_{6}\right)^{2-}$, in $[\mathrm{K}(\text { crypt })]_{2}\left[\left(\mathrm{C}_{9} \mathrm{H}_{7}\right)_{2} \mathrm{Dy}\left(\mu-\eta^{5}: \eta^{1}-\mathrm{C}_{9} \mathrm{H}_{6}\right)\right]_{2}{ }^{.53}$

\section{Dysprosium}

Reduction of 1-Dy produced dark red crystals suitable for X-ray diffraction that also appeared to be isomorphous with 2-Nd. Instead, the crystallographic data were best modeled as a mixture of the divalent [K(crypt)][(( $\left.{ }^{\mathrm{Ad}, \mathrm{Me}} \mathrm{ArO}\right)_{3}$ mes $\left.) \mathrm{Dy}\right]$, 2-Dy, and the trivalent hydroxide $\left.[\mathrm{K}(\mathrm{crypt})]\left[\left({ }^{\mathrm{Ad}, \mathrm{Me}} \mathrm{ArO}\right)_{3} \mathrm{mes}\right) \mathrm{Dy}(\mathrm{OH})\right]$, 4-Dy, in a $2: 3$ ratio. Like the 2-Ln/3-Ln mixtures, 2-Dy and 4-Dy lie on a threefold axis with the same ligand environment, Fig. 6, in which Dy(1) represents the metal center for 2-Dy and Dy(2)

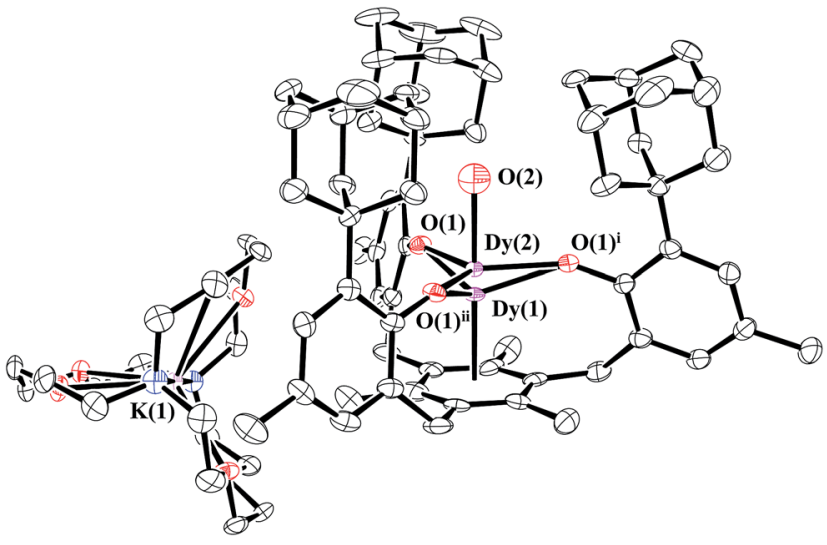

Fig. 6 Molecular structure of [K(crypt)][(( $\left.\left.\left.{ }^{\mathrm{Ad}, \mathrm{Me}} \mathrm{ArO}\right)_{3} \mathrm{mes}\right) \mathrm{Dy}\right] /[\mathrm{K}(\mathrm{crypt})]$ [( $\left.\left.\left({ }^{\mathrm{Ad}, \mathrm{Me}} \mathrm{ArO}\right)_{3} \mathrm{mes}\right) \mathrm{Dy}(\mathrm{OH})\right], 2-\mathrm{Dy} / 4-\mathrm{Dy}$, with thermal ellipsoids drawn at the $50 \%$ probability level. Hydrogen atoms and a disordered ether molecule are omitted for clarity. Dy(1) is the metal position in 2-Dy and Dy(2) is the metal position in 4-Dy.

represents the metal center for 4-Dy. The origin of the hydroxide ligand in 4-Dy is unknown. We include the data on this mixed crystal here, because it does contain a $\mathrm{Dy}^{2+}$ complex and shows that the $\mathrm{Ln}^{2+}$ complexes can co-crystallize with hydroxides as well as hydrides.

Given the unusual hydroxide result above, the Dy reaction was examined further with 18-crown-6. Reduction of 1-Dy with $\mathrm{K}$ in the presence of 18-crown-6 instead of 2.2.2-cryptand gave a dark colored solution similar to that observed to form the 2Dy/4-Dy mixture. Crystallization of this product gave single crystals that were modeled as a $1: 1$ mixture of [K(18-crown6)(THF $\left.\left.)_{2}\right]\left[\left({ }^{\mathrm{Ad}, \mathrm{Me}} \mathrm{ArO}\right)_{3} \mathrm{mes}\right) \mathrm{Dy}\right], 5-\mathrm{Dy}$, and the trivalent hydride, $\left.\left[\mathrm{K}(18 \text {-crown-6)(THF })_{2}\right)\right]\left[\left(\left({ }^{\mathrm{Ad}, \mathrm{Me}} \mathrm{ArO}\right)_{3} \mathrm{mes}\right) \mathrm{DyH}\right]$, 6-Dy (see ESI $\left.\dagger\right)$. This 5-Dy/6-Dy mixture is analogous to the 2-Ln/3-Ln mixtures, except that the countercation is $\left[\mathrm{K}\left((18-\text { crown- } 6)(\mathrm{THF})_{2}\right]^{+}\right.$rather than $[\mathrm{K}(\mathrm{crypt})]^{+}$.

Subsequently, the reduction of 1-Dy was re-examined and single crystals containing a mixture of the $\mathrm{Dy}^{2+}$ complex and the $\mathrm{Dy}^{3+}$ hydride were obtained, i.e. 2-Dy/3-Dy. In this case the ratio of $\mathrm{Dy}^{2+}$ to $\mathrm{Dy}^{3+}$ hydride was modeled by a $63: 37$ mixture.

\section{Structural comparisons}

Structural data on 2-Nd and the co-crystallized 2-Gd/3-Gd, 2-Dy/ 3-Dy, 2-Er/3-Er, 2-Dy/4-Dy, and 5-Dy/6-Dy mixtures are given in Table 2, along with the data for 2-U. In contrast to the data on the $\mathrm{Ln}^{3+}$ 1-Ln complexes shown in Table 1, the structural data on the mixtures presented in Table 2 do not follow the regular changes in distances with radial size for either the $\mathrm{Ln}^{2+}$ complexes, 2-Ln and 5-Dy, or for the $\mathrm{Ln}^{3+}$ complexes, 3-Ln, 4-Dy, and 6-Dy. The substantial differences in the metrical parameters of the $[\mathrm{K}(\mathrm{crypt})]^{+}$and $\left[\mathrm{K}(18 \text {-crown-6)(THF })_{2}\right]^{+}$salts of the $\left[\left(\left(^{\mathrm{Ad}, \mathrm{Me}} \mathrm{ArO}\right)_{3} \mathrm{mes}\right) \mathrm{Dy}\right]^{-}$anion, 2-Dy and 5-Dy, illustrate the complicated nature of these structural data. As a result, only the metrical data for 2-U and 2-Nd will be compared.

A comparison of the divalent complexes 2-Nd and 2-U, along with their trivalent analogs, is given in Table 3. The structural data on 2-Nd show that the metal center is $0.123 \AA$ closer to the 
Table 2 Selected bond lengths ( $(\AA)$ and angles $\left(^{\circ}\right)$ of 2-U, 2-Nd, 2-Gd/3-Gd, 2-Er/3-Er, 2-Dy/4-Dy, and 5-Dy/6-Dy

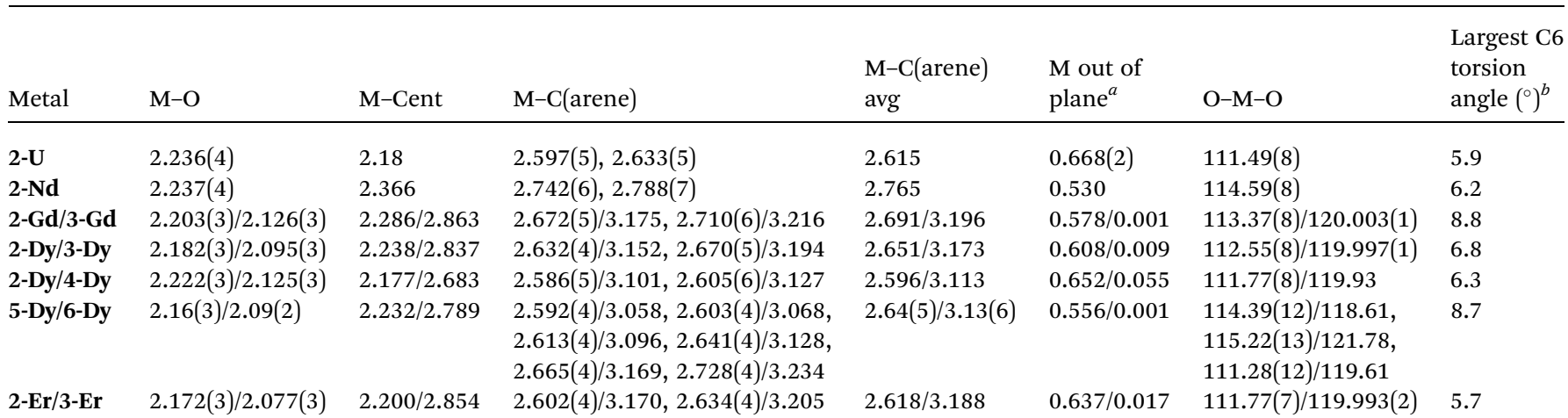

${ }^{a}$ Distance of $\mathrm{M}$ from the plane defined by the three $\mathrm{O}$ atoms of the $\left(\left({ }^{\mathrm{Ad}, \mathrm{Me}} \mathrm{ArO}\right){ }_{3} \mathrm{mes}\right)^{3-}$ ligand. ${ }^{b}$ The largest dihedral angle between adjacent threecarbon planes in the mesitylene ring.

Table 3 Differences $(\Delta)$ in bond distances $(\AA)$ and angles $\left(^{\circ}\right)$ between 2-Nd and $2-U$ and their trivalent analogs, 1-Nd and $1-U$, respectively

\begin{tabular}{lllll}
\hline Metal & $\Delta(\mathrm{M}-\mathrm{O})$ & $\Delta(\mathrm{M}-\mathrm{Cent})$ & $\begin{array}{l}\Delta(\mathrm{M} \text { out of } \\
\text { plane })^{a}\end{array}$ & $\begin{array}{l}\Delta(\text { largest } \\
\text { C6 torsion angle })\end{array}$ \\
\hline $\mathbf{U}$ & 0.068 & -0.170 & 0.193 & -0.9 \\
Nd & 0.050 & -0.123 & 0.262 & 0.6
\end{tabular}

${ }^{a}$ Distance of $\mathrm{M}$ from the plane defined by the three $\mathrm{O}$ atoms of the $\left(\left({ }^{\text {Ad,Me }} \mathrm{ArO}\right)_{3} \mathrm{mes}\right)^{3-}$ ligand.

arene centroid than in 1-Nd. This change is not as large as the $0.17 \AA$ difference between 1-U and 2-U, which is likely due to the limited radial extension of the $4 \mathrm{f}$ orbitals $v s$. the $5 \mathrm{f}$ orbitals. ${ }^{56}$ Just as in $\mathbf{2 - U}$, the arene carbon atoms are approximately planar in 2-Nd and the $\mathrm{C}-\mathrm{C}$ (arene) bond lengths only increase by approximately $0.01 \AA$ A This is consistent with reduction of the

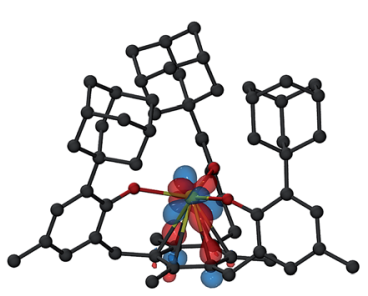

SOMO

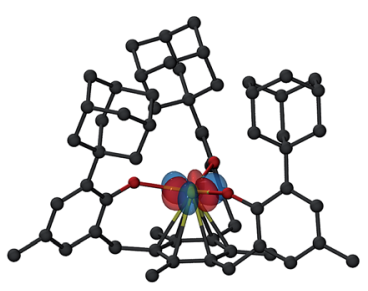

SOMO-2

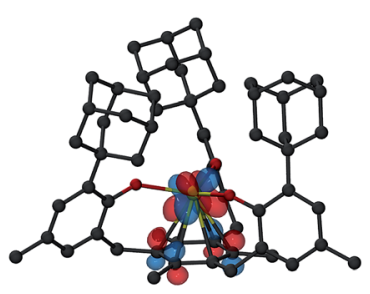

SOMO-1

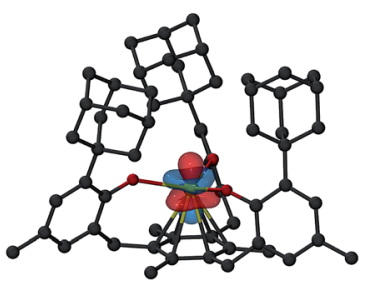

SOMO-3
Fig. 7 Isosurfaces for the four highest singly-occupied molecular orbitals of $2-\mathrm{Nd}$ corresponding to a contour value of 0.05 . Hydrogen atoms are omitted for clarity. metal and not the arene. As analyzed for uranium, the contraction of the $\mathbf{M}$-(arene centroid) distance between 1-Nd and 2-Nd could suggest a greater interaction between the metal and arene due to a change in charge distribution.

\section{Theoretical insight}

Density functional theory (DFT) calculations using the TaoPerdew-Staroverov-Scuseria (TPSS) functional ${ }^{57}$ and mixed basis sets were carried out on 1-Nd, 2-Nd, and 2-Gd (see ESI for further details $\dagger$ ). ${ }^{\mathbf{5 8 5}}$ For 1-Nd and 2-Nd, the calculated structural parameters match those observed within $0.04 \AA$ (Table S5, ESI $\dagger$ ). The three valence electrons of 1-Nd occupy predominantly $4 \mathrm{f}$-type orbitals with little observable interaction with the mesitylene ring. This differs from 1-U as expected for a $4 \mathrm{f} v s .5 \mathrm{f}$ system. ${ }^{11}$ Calculations on $\mathbf{2}$-Nd suggest a quintet ground state with two electrons in f orbitals and two electrons in $\mathrm{f} / \pi^{*}$ orbitals of $\delta$ symmetry (see Tables S6 and S7 $\dagger$ ); the corresponding four SOMOs are shown in Fig. 7. This orbital picture resembles that of 2-U. ${ }^{12}$ The lowest unoccupied orbital with d-orbital character for 2-Nd is about $2.9 \mathrm{eV}$ above the HOMO and has $\mathrm{d}_{\mathrm{z}}{ }^{2}$ character (see Fig. S11, ESI $\dagger$ ). Hence, the DFT calculations suggest that the $\left(\left({ }^{\mathrm{Ad}, \mathrm{Me}} \mathrm{ArO}\right)_{3} \mathrm{mes}\right)^{3-}$ ligand system favors a formal $4 \mathrm{f}^{4}$ electron configuration for $\mathrm{Nd}^{2+}$ rather than a $4 \mathrm{f}^{3} 5 \mathrm{~d}^{1}$ configuration

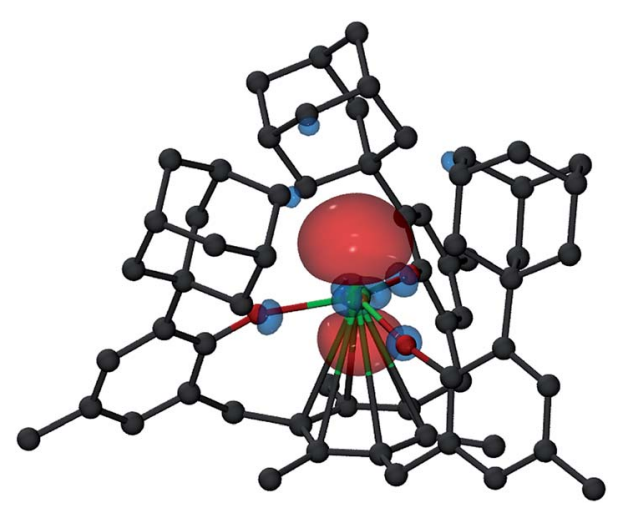

Fig. 8 Isosurface of the highest SOMO of nonet 2-Gd with a contour value of 0.05 . Hydrogen atoms are omitted for clarity. 
postulated for $\mathrm{Nd}^{2+}$ in the $\left(\mathrm{Cp}_{3}^{\prime}\right)^{3-}$ environment. ${ }^{5}$ This assignment is consistent with $\mathrm{Nd}^{2+}$ being a configurational crossover ion and is further supported by the $5 \mathrm{f}^{4}$ configuration found for $[\mathrm{K}(\mathrm{crypt})]\left[\left(\left({ }^{\mathrm{Ad}, \mathrm{Me}} \mathrm{ArO}\right)_{3} \mathrm{mes}\right) \mathrm{U}\right], 2-\mathrm{U}$, vs. the $5 \mathrm{f}^{3} 6 \mathrm{~d}^{1}$ configurations for $[\mathrm{K}($ crypt $)]\left[\mathrm{Cp}_{3}{ }_{3} \mathrm{U}\right]^{6}$ and $[\mathrm{K}($ crypt $)]\left[\mathrm{Cp}^{\prime \prime}{ }_{3} \mathrm{U}\right] .^{.}$.

DFT calculations on 2-Gd proved to be more challenging. The ground state of 2-Gd is a nonet (8 unpaired electrons) with a $4 \mathrm{f}^{7}(5 \mathrm{~d} / 6 \mathrm{~s})^{1}$ configuration for the Gd atom (Fig. 8). This result is similar to the $4 \mathrm{f}^{7} 5 \mathrm{~d}^{1}$ configuration observed for [K(crypt)] $\left[\mathrm{Cp}_{3}^{\prime} \mathrm{Gd}\right]$, except that the SOMO has $6 \mathrm{~s}$ as well as $5 \mathrm{~d}$ character. A nonet ground state is also supported by the observable EPR spectrum for 2-Gd (Fig. 5). However, the computed metal-arene bond-distance $(3.17 \AA)$ is larger than the experimentally observed bond-distance $(2.29 \AA)$ and the calculated metal outof-plane distortion $(-0.28 \AA)$ is in a direction opposite to the experimental value $(0.578 \AA)$, see Table $\mathrm{S} 5, \dagger$ indicating that the DFT results for 2-Gd need to be interpreted with caution. The potential energy profile along the Gd out-of-plane distortion is fairly shallow and has several minima with different electronic character, and the DFT picture may not adequately capture the multi-configurational nature of the nonet ground state. In any case, it appears that the $\left(\left({ }^{\mathrm{Ad}, \mathrm{Me}} \mathrm{ArO}\right)_{3} \mathrm{mes}\right)^{3-}$ ligand system can favor $4 \mathrm{f}^{n+1}$ over $4 \mathrm{f}^{n} 5 \mathrm{~d}^{1}$ with the configurational crossover ion, $\mathrm{Nd}^{2+}$, but this effect is not strong enough to overcome the stabilization derived from a $4 \mathrm{f}^{7}$ half-filled shell in $\mathrm{Gd}^{2+}$.

\section{Conclusion}

Tris(aryloxide) arene lanthanide(III) complexes, [(( $\left.{ }^{\mathrm{Ad}, \mathrm{Me}} \mathrm{ArO}\right)_{3^{-}}$ mes)Ln], 1-Ln, analogous to $\left[\left(\left({ }^{\mathrm{Ad}, \mathrm{Me}} \mathrm{ArO}\right)_{3} \mathrm{mes}\right) \mathrm{U}\right], \mathbf{1 - U},{ }^{11}$ have been synthesized and characterized by single-crystal X-ray diffraction for $\mathrm{Ln}=\mathrm{Nd}$, Gd, Dy, and Er. The four trivalent Ln complexes show structural regularity in metal ligand distances based on their decreasing radial size from Nd to Er. Complex 1$\mathbf{U}$ appears to have greater interaction with the tris(aryloxide) arene ligand consistent with greater radial extension of the $5 \mathrm{f}$ orbitals. Reduction of 1-Ln generates four new $\mathrm{Ln}^{2+}$ complexes, $[\mathrm{K}(\mathrm{crypt})]\left[\left(\left({ }^{\mathrm{Ad}, \mathrm{Me}} \mathrm{ArO}\right)_{3} \mathrm{mes}\right) \mathrm{Ln}\right]$, 2-Ln, for Nd, Gd, Dy, and $\mathrm{Er}$ as well as the 18-crown-6 variant, [K(18-crown-6)(THF $\left.)_{2}\right]$ $\left[\left(\left({ }^{\mathrm{Ad}, \mathrm{Me}} \mathrm{ArO}\right)_{3} \mathrm{mes}\right) \mathrm{Dy}\right]$, 5-Dy. 2-Gd, 2-Er, and 5-Dy co-crystallize with $\mathrm{Ln}^{3+}$ hydrides, [K(crypt)][(( $\left.\left.\left.{ }^{\mathrm{Ad}, \mathrm{Me}} \mathrm{ArO}\right)_{3} \mathrm{mes}\right) \mathrm{LnH}\right]$, 3-Ln, or $\left[\mathrm{K}\left((18 \text {-crown-6)(THF })_{2}\right)\right]\left[\left(\left({ }^{\mathrm{Ad}, \mathrm{Me}} \mathrm{ArO}\right)_{3} \mathrm{mes}\right) \mathrm{DyH}\right], \quad$ 6-Dy. This suggests that the $\left.\left({ }^{\left({ }^{A d, M e}\right.} \mathrm{ArO}\right){ }_{3} \mathrm{mes}\right)^{3-}$ ligand environment is especially effective at promoting high reactivity.

DFT calculations indicate that the one $\mathrm{Ln}^{2+}$ complex isolated without $\mathrm{Ln}^{3+}$ co-crystallization, 2-Nd, appears to have a $4 \mathrm{f}^{4}$ electron configuration with two electrons in $4 \mathrm{f} / \pi^{*}$ orbitals and two electrons in other $4 \mathrm{f}$ orbitals. This contrasts with the $4 \mathrm{f}^{3} 5 \mathrm{~d}^{1}$ configuration of $\left[\mathrm{Cp}_{3}{ }_{3} \mathrm{Nd}\right]^{1-}$ and is consistent with $\mathrm{Nd}^{2+}$ being a configurational crossover ion. Comparison of 2-Nd with congeneric and isomorphous $\mathbf{2}-\mathbf{U}$ shows closer interaction of the metal with the ligand in the case of the $5 \mathrm{f} v s$. $4 \mathrm{f}$ metal, which is consistent with the relative radial extensions of these orbitals. EPR data and DFT calculations on [K(crypt)][( $\left({ }^{\mathrm{Ad}, \mathrm{Me}} \mathrm{ArO}\right)_{3}$ mes $)$ $\left.\mathrm{Gd}] /[\mathrm{K}(\mathrm{crypt})]\left[\left({ }^{\mathrm{Ad}, \mathrm{Me}} \mathrm{ArO}\right)_{3} \mathrm{mes}\right) \mathrm{GdH}\right], \quad$ 2-Gd/3-Gd, tentatively suggest a $4 \mathrm{f}^{7} 5 \mathrm{~d}^{1}$ electron configuration that retains a half-filled uf shell for $\mathrm{Gd}^{2+}$ in the $\left[\left({ }^{\mathrm{Ad}, \mathrm{Me}} \mathrm{ArO}\right){ }_{3} \mathrm{mes}\right]^{3-}$ coordination environment, although the poor agreement of the DFT metalarene bond distance with the X-ray data merits further investigation. Overall, the results suggest that the $\left[\left({ }^{\mathrm{Ad}, \mathrm{Me}} \mathrm{ArO}\right)_{3} \mathrm{mes}\right]^{3-}$ ligand has considerable flexibility in binding heavy metals.

\section{Experimental details}

The syntheses and manipulations described below were conducted under an argon atmosphere with rigorous exclusion of air and water using glovebox, vacuum line, and Schlenk techniques. Solvents were sparged with ultrahigh purity (UHP) grade argon (Airgas) and passed through columns containing Q-5 and molecular sieves before use. NMR solvents (Cambridge Isotope Laboratories) were dried over NaK/benzophenone, degassed by three freeze-pump-thaw cycles, and vacuum-transferred before use. $\left[\mathrm{Ln}\left(\mathrm{N}\left(\mathrm{SiMe}_{3}\right)_{2}\right)_{3}\right](\mathrm{Ln}=\mathrm{Nd}, \mathrm{Gd}, \mathrm{Dy}, \mathrm{Er}),{ }^{60} \mathrm{KC}_{8},{ }^{61}$ and $\left({ }^{\mathrm{Ad}, \mathrm{Me}} \mathrm{ArOH}\right){ }_{3} \mathrm{mes},{ }^{11}$ were prepared according to literature. 2.2.2Cryptand, $\quad 4,7,13,16,21,24$-hexaoxa-1,10-diazabicyclo[8.8.8] hexacosane (Acros Organics), was placed under vacuum $\left(10^{-3}\right.$ Torr) for $12 \mathrm{~h}$ before use. 18-Crown-6 (Aldrich) was sublimed before use. ${ }^{1} \mathrm{H}$ NMR $(500 \mathrm{MHz})$ spectra were obtained on a Bruker GN500 or CRYO500 MHz spectrometer at $298 \mathrm{~K}$. IR samples were prepared as $\mathrm{KBr}$ pellets and the spectra were obtained on either a Varian 1000 or Jasco 4700 FT-IR spectrometer. Elemental analyses were performed on a PerkinElmer 2400 series II CHNS elemental analyzer. Electronic absorption spectra were obtained in THF or benzene at $298 \mathrm{~K}$ using a Varian Cary 50 Scan UV-vis or Jasco V-670 UV/Vis/NIR/MIR absorption spectrometer. EPR spectra were collected using Xband frequency $(9.3-9.8 \mathrm{GHz})$ on a Bruker EMX spectrometer equipped with an ER041XG microwave bridge and the magnetic field was calibrated with DPPH $(g=2.0036)$.

\section{$\left.\left[\left({ }^{\mathrm{Ad}, \mathrm{Me}} \mathbf{A r O}\right)_{3} \mathrm{mes}\right) \mathbf{N d}\right], \mathbf{1 - N d}$}

In an argon-filled glovebox, a sealable $100 \mathrm{~mL}$ side-arm Schlenk flask equipped with a greaseless stopcock was charged with a solution of $\left({ }^{\mathrm{Ad}, \mathrm{Me}} \mathrm{ArOH}\right)_{3}$ mes $(256 \mathrm{mg}, 0.290 \mathrm{mmol})$ in benzene $(40 \mathrm{~mL})$ and a magnetic stir bar. A solution of $\left[\mathrm{Nd}\left(\mathrm{N}\left(\mathrm{SiMe}_{3}\right)_{2}\right)_{3}\right]$ (251 $\mathrm{mg}, 0.305 \mathrm{mmol})$ in benzene $(40 \mathrm{~mL})$ was slowly added to the stirred solution. Higher concentrations resulted in gel-like precipitates and low yields. The flask was attached to a Schlenk line and the mixture was stirred and heated at reflux for $18 \mathrm{~h}$. The flask was brought back into the glovebox, the solution was filtered, and the solvent was removed from the colorless filtrate under vacuum. The resulting pale-blue solid was washed with hexanes then extracted into benzene $(15 \mathrm{~mL})$ and filtered. Toluene $(5 \mathrm{~mL})$ was added to the filtrate and removal of solvent under vacuum afforded 1-Nd as a pale-blue powder (163 mg, 56\%). Blue single crystals of 1-Nd, suitable for X-ray diffraction, were grown from slow evaporation of a $\mathrm{C}_{6} \mathrm{D}_{6}$ solution. ${ }^{1} \mathrm{H}$ NMR $\left(\mathrm{C}_{6} \mathrm{D}_{6}\right): \delta 16.0(\mathrm{~s}, 3 \mathrm{H}), 10.7(\mathrm{~s}, 3 \mathrm{H}), 7.0$ (s, 9H), 3.5 (br s, 18H), 1.1 (br s, 9H), 1.00 (br s, 6H), -6.2 (s, 9H), -7.2 (s, 9H), -16.3 (s, 9H). IR: $3074 \mathrm{w}, 2898 \mathrm{~s}, 2845 \mathrm{w}, 2675 \mathrm{w}$, $2652 \mathrm{w}, 1730 \mathrm{w}, 1601 \mathrm{w}, 1568 \mathrm{w}, 1492 \mathrm{~m}, 1445 \mathrm{~s}, 1380 \mathrm{~m}, 1340 \mathrm{~m}$, $1305 \mathrm{~m}, 1285 \mathrm{~s}, 1245 \mathrm{~s}, 1205 \mathrm{~m}, 1184 \mathrm{~m}, 1160 \mathrm{~m}, 1113 \mathrm{w}, 1100 \mathrm{~m}$, $1066 \mathrm{~s}, 1019 \mathrm{~m}, 980 \mathrm{~m}, 960 \mathrm{~m}, 915 \mathrm{~m}, 886 \mathrm{~m}, 835 \mathrm{~s}, 820 \mathrm{~s}, 808 \mathrm{~s}$, 
737m, 733s, 729m, 694m, 679w, 631w. Anal. calcd for $\mathrm{C}_{63} \mathrm{H}_{75} \mathrm{NdO}_{3}$ : C, 73.86; H, 7.38. Found: C, 74.09; H, 7.35.

\section{$\left[\left(\left({ }^{\mathrm{Ad}, \mathrm{Me}} \mathrm{ArO}\right)_{3} \mathrm{mes}\right) \mathrm{Gd}\right]$, 1-Gd}

As described for 1-Nd, a solution of $\left[\mathrm{Gd}\left(\mathrm{N}\left(\mathrm{SiMe}_{3}\right)_{2}\right)_{3}\right](73 \mathrm{mg}$, $0.115 \mathrm{mmol})$ in benzene $(40 \mathrm{~mL})$ was slowly added to a stirred solution of $\left({ }^{\mathrm{Ad}, \mathrm{Me}} \mathrm{ArOH}\right)_{3}$ mes $(100 \mathrm{mg}, 0.113 \mathrm{mmol})$ in benzene $(30 \mathrm{~mL})$ to afford 1-Gd as an off-white solid (104 mg, 86\%). Colorless single crystals of 1-Gd, suitable for X-ray diffraction, were grown from an $\mathrm{Et}_{2} \mathrm{O} /$ hexane solution at $-35{ }^{\circ} \mathrm{C}$. IR: $3067 \mathrm{w}$, $3017 \mathrm{w}, 2960 \mathrm{~s}, 2897 \mathrm{~s}, 2849 \mathrm{~s}, 2732 \mathrm{w}, 2672 \mathrm{w}, 2652 \mathrm{w}, 1739 \mathrm{w}$, $1605 \mathrm{w}, 1568 \mathrm{w}, 1545 \mathrm{w}, 1494 \mathrm{~m} 1453 \mathrm{~s}, 1377 \mathrm{~m}, 1366 \mathrm{~m}, 1354 \mathrm{~m}$, $1341 \mathrm{~m}, 1317 \mathrm{~s}, 1308 \mathrm{~s}, 1284 \mathrm{~s}, 1252 \mathrm{~s}, 1209 \mathrm{~s}, 1184 \mathrm{~m}, 1161 \mathrm{~m}$, $1116 \mathrm{w}, 1102 \mathrm{~m}, 1068 \mathrm{~m}, 1037 \mathrm{w}, 1017 \mathrm{~m}, 983 \mathrm{~m}, 960 \mathrm{~m}, 937 \mathrm{w}$, $911 \mathrm{~m}, 915 \mathrm{~m}, 888 \mathrm{~m}, 881 \mathrm{~m}, 858 \mathrm{~s}, 835 \mathrm{~s}, 820 \mathrm{~s}, 809 \mathrm{~s}, 765 \mathrm{~m}, 748 \mathrm{~m}$, $729 \mathrm{~m}, 694 \mathrm{~m}, 683 \mathrm{w}, 668 \mathrm{w}, 653 \mathrm{w}, 646 \mathrm{w}, 643 \mathrm{w}, 607 \mathrm{w}$. Anal. calcd for $\mathrm{C}_{63} \mathrm{H}_{75} \mathrm{GdO}_{3}$ : C, 72.93; H, 7.29. Found: C, 73.04; H, 7.26.

\section{[(( $\left.\left.\left.{ }^{\mathrm{Ad}, \mathrm{Me}} \mathrm{ArO}\right)_{3} \mathrm{mes}\right) \mathrm{Dy}\right]$, 1-Dy}

As described for 1-Nd, a solution of $\left[\mathrm{Dy}\left(\mathrm{N}\left(\mathrm{SiMe}_{3}\right)_{2}\right)_{3}\right](298 \mathrm{mg}$, $0.354 \mathrm{mmol})$ in benzene $(20 \mathrm{~mL})$ was slowly added to a stirred solution of $\left({ }^{\mathrm{Ad}, \mathrm{Me}} \mathrm{ArOH}\right){ }_{3}$ mes $(303 \mathrm{mg}, 0.343 \mathrm{mmol})$ in benzene $(30 \mathrm{~mL})$ to afford 1-Dy as an off-white solid (236 mg, 66\%). Colorless single crystals of 1-Dy, suitable for X-ray diffraction, were grown from an $\mathrm{Et}_{2} \mathrm{O} /$ hexane solution at $-35^{\circ} \mathrm{C}$. IR: $3068 \mathrm{w}$, 2946s, 2899s, 2844s, 2725w, 2675w, 2653w, $1745 \mathrm{w}, 1605 \mathrm{w}$, $1568 \mathrm{w}, 1545 \mathrm{w}, 1495 \mathrm{w}, 1447 \mathrm{~s}, 1379 \mathrm{~m}, 1366 \mathrm{~m}, 1354 \mathrm{~m}, 1341 \mathrm{~m}$, $1315 \mathrm{~m}, 1306 \mathrm{~m}, 1287 \mathrm{~s}, 1250 \mathrm{~s}, 1208 \mathrm{~m}, 1186 \mathrm{~m}, 1161 \mathrm{~m}, 1114 \mathrm{w}$, $1101 \mathrm{~m}, 1068 \mathrm{~m}, 1035 \mathrm{~m}, 1020 \mathrm{~m}, 980 \mathrm{~m}, 963 \mathrm{~m}, 937 \mathrm{w}, 923 \mathrm{~m}$, $917 \mathrm{~m}, 878 \mathrm{w}, 880 \mathrm{w}, 845 \mathrm{~m}, 835 \mathrm{~s}, 822 \mathrm{~s}, 809 \mathrm{~s}, 767 \mathrm{~m}, 748 \mathrm{~m}, 728 \mathrm{~m}$, $693 \mathrm{w}, 674 \mathrm{~s}, 666 \mathrm{w}, 650 \mathrm{w}, 631 \mathrm{w}, 606 \mathrm{w}$. Anal. calcd for $\mathrm{C}_{63} \mathrm{H}_{75} \mathrm{DyO}_{3}$ : C, 72.56; H, 7.25. Found: C, 72.28; H, 7.31.

\section{$\left[\left(\left({ }^{\mathrm{Ad}, \mathrm{Me}} \mathrm{ArO}\right)_{3} \mathrm{mes}\right) \mathrm{Er}\right]$, 1-Er}

As described for 1-Nd, a solution of $\left[\operatorname{Er}\left(\mathrm{N}\left(\mathrm{SiMe}_{3}\right)_{2}\right)_{3}\right](78 \mathrm{mg}$, $0.120 \mathrm{mmol})$ in benzene $(20 \mathrm{~mL})$ was slowly added to a stirred solution of $\left({ }^{\mathrm{Ad}, \mathrm{Me}} \mathrm{ArOH}\right)_{3}$ mes $(100 \mathrm{mg}, 0.113 \mathrm{mmol})$ in benzene $(20 \mathrm{~mL})$ to afford 1-Er as a pink solid (70 mg, 59\%). Pale pink single crystals of 1-Er, suitable for X-ray diffraction, were grown from an Et2O/hexane solution at $-35{ }^{\circ} \mathrm{C}$. IR: $3075 \mathrm{w}, 2898 \mathrm{~s}$, 2845 s, 2675w, 2653w, 1733w, 1601w, 1568w, 1542w, 1492m, $1447 \mathrm{~s}, 1381 \mathrm{~m}, 1341 \mathrm{~m}, 1305 \mathrm{~m}, 1286 \mathrm{~s}, 1246 \mathrm{~s}, 1207 \mathrm{~m}, 1185 \mathrm{~m}$, $1161 \mathrm{~m}, 1117 \mathrm{w}, 1100 \mathrm{~m}, 1066 \mathrm{~s}, 1019 \mathrm{~m}, 980 \mathrm{w}, 961 \mathrm{w}, 915 \mathrm{~m}, 878 \mathrm{w}$, $856 \mathrm{~m}, 836 \mathrm{~s}, 821 \mathrm{~s}, 809 \mathrm{~s}, 766 \mathrm{~m}, 748 \mathrm{~m}, 735 \mathrm{~m}, 695 \mathrm{~m}, 680 \mathrm{w}, 652 \mathrm{w}$, 631w. Anal. calcd for $\mathrm{C}_{63} \mathrm{H}_{75} \mathrm{ErO}_{3}$ : C, 72.23; H, 7.22. Found: C, 72.88; H, 7.80 .

\section{[K(crypt)][(( $\left.\left.\left.{ }^{\mathrm{Ad}, \mathrm{Me}} \mathrm{ArO}\right)_{3} \mathrm{mes}\right) \mathrm{Nd}\right]$, 2-Nd}

In an argon-filled glovebox, [(( $\left.\left.\left.{ }^{\mathrm{Ad}, \mathrm{Me}} \mathrm{ArO}\right){ }_{3} \mathrm{mes}\right) \mathrm{Nd}\right], \mathbf{1 - N d}(60 \mathrm{mg}$, $0.059 \mathrm{mmol}$ ), was combined with 2.2.2-cryptand (22 $\mathrm{mg}, 0.058$ $\mathrm{mmol}$ ) in a vial containing a magnetic stir bar and dissolved in $1: 1 \mathrm{THF} / \mathrm{C}_{6} \mathrm{H}_{6}(4 \mathrm{~mL}) . \mathrm{KC}_{8}(15 \mathrm{mg}, 0.11 \mathrm{mmol})$ was quickly added to the pale blue solution. The reaction immediately turned brown. After $2 \mathrm{~min}$, the solution was filtered to remove the graphite. The resulting red-orange solution was layered with
$\mathrm{Et}_{2} \mathrm{O}(15 \mathrm{~mL})$ and stored at $-35{ }^{\circ} \mathrm{C}$ for $48 \mathrm{~h}$ to produce brown/ orange crystals of 2-Nd suitable for X-ray diffraction $(16 \mathrm{mg}$, 23\%). IR: 3065w, 2965m, 2897s, 2845s, 2812m, 2727w, 2676w, $2653 \mathrm{w}, 1730 \mathrm{w}, 1599 \mathrm{w}, 1560 \mathrm{~m}, 1477 \mathrm{~m}, 1444 \mathrm{~s}, 1374 \mathrm{w}, 1360 \mathrm{~m}$, $1354 \mathrm{~s}, 1341 \mathrm{w}, 1313 \mathrm{~m}, 1284 \mathrm{~s}, 1275 \mathrm{~s}, 1256 \mathrm{~s}, 1251 \mathrm{~s}, 1210 \mathrm{w}$, $1184 \mathrm{w}, 1163 \mathrm{w}, 1134 \mathrm{~m}, 1106 \mathrm{~s}, 1082 \mathrm{~m}, 1059 \mathrm{~m}, 1046 \mathrm{w}, 1000 \mathrm{w}$, 980w, 950m, 935m, 911w, 903w, 895w, 876w, 856m, 831m, $818 \mathrm{~m}, 804 \mathrm{~m}, 767 \mathrm{w}, 748 \mathrm{w}, 727 \mathrm{w}, 720 \mathrm{w}, 715 \mathrm{w}, 707 \mathrm{w}, 693 \mathrm{w}, 684 \mathrm{w}$, $680 \mathrm{w}, 677 \mathrm{w}, 670 \mathrm{w}, 667 \mathrm{w}, 663 \mathrm{w}, 657 \mathrm{w}, 651 \mathrm{w}, 647 \mathrm{w}, 639 \mathrm{w}, 631 \mathrm{w}$, 625w, 618w, 612w, 609w, 603w. UV-vis (THF) $\lambda_{\max } \mathrm{nm}$ $\left(\varepsilon, \mathrm{M}^{-1} \mathrm{~cm}^{-1}\right.$ ): 299 (19 500), 387 (4000 shoulder), 416 (4200), 480 (2000 shoulder), 600 (300). Anal. calcd for $\mathrm{C}_{81} \mathrm{H}_{111} \mathrm{KN}_{2} \mathrm{NdO}_{9}: \mathrm{C}$, 67.56; H, 7.77; N, 1.95. Found: C, 66.23; H, 7.66; N, 1.71. The found $\mathrm{CHN}$ ratio of $\mathrm{C}_{81} \mathrm{H}_{111.6} \mathrm{~N}_{1.8}$ is consistent with the formula and suggests incomplete combustion.

\section{$\left.[\mathrm{K}(\mathrm{crypt})]\left[\left({ }^{\mathrm{Ad}, \mathrm{Me}} \mathrm{ArO}\right)_{3} \mathrm{mes}\right) \mathrm{Gd}\right]$ and [K(crypt) $)\left[\left(\left({ }^{\mathrm{Ad}, \mathrm{Me}} \mathrm{ArO}\right)_{3} \mathrm{mes}\right)\right.$ GdH], 2-Gd/3-Gd}

As described for 2-Nd, [(( $\left.\left.\left.{ }^{\mathrm{Ad}, \mathrm{Me}} \mathrm{ArO}\right)_{3} \mathrm{mes}\right) \mathrm{Gd}\right], \mathbf{1 - G d},(60 \mathrm{mg}, 0.059$ $\mathrm{mmol}$ ) and 2.2.2-cryptand (23 $\mathrm{mg}, 0.060 \mathrm{mmol}$ ) were dissolved in $1: 1 \mathrm{THF} / \mathrm{C}_{6} \mathrm{H}_{6}(4 \mathrm{~mL})$ to form an off-white solution, which was combined with $\mathrm{KC}_{8}(20 \mathrm{mg}, 0.15 \mathrm{mmol})$ to produce red crystals suitable for X-ray diffraction $(51 \mathrm{mg})$. The crystals were characterized as a co-crystallized mixture of [K(crypt)] $\left[\left(\left({ }^{\mathrm{Ad}, \mathrm{Me}} \mathrm{ArO}\right)_{3} \mathrm{mes}\right) \mathrm{Gd}\right], \quad$ 2-Gd, and $[\mathrm{K}(\mathrm{crypt})]\left[\left(\left({ }^{\mathrm{Ad}, \mathrm{Me}} \mathrm{ArO}\right)_{3} \mathrm{mes}\right)\right.$ $\mathrm{GdH}$ ], 3-Gd, of an approximate $65: 35$ ratio. UV-vis (THF) $\lambda_{\text {max }} \mathrm{nm}\left(\varepsilon, \mathrm{M}^{-1} \mathrm{~cm}^{-1}\right): 305$ (22 000), 330 (6000 shoulder), 426 (4000), 520 (2000 shoulder), 580 (400).

\section{$[\mathrm{K}(\mathrm{crypt})]\left[\left(\left({ }^{\mathrm{Ad}, \mathrm{Me}} \mathrm{ArO}\right)_{3} \mathrm{mes}\right) \mathrm{Er}\right]$ and $[\mathrm{K}(\mathrm{crypt})]\left[\left({ }^{\mathrm{Ad}, \mathrm{Me}} \mathrm{ArO}\right)_{3} \mathrm{mes}\right)$ ErH], 2-Er/3-Er}

As described for 2-Nd, [(( $\left.\left.\left.{ }^{\mathrm{Ad}, \mathrm{Me}} \mathrm{ArO}\right){ }_{3} \mathrm{mes}\right) \mathrm{Er}\right], \mathbf{1 - E r},(45 \mathrm{mg}, 0.043$ $\mathrm{mmol}$ ) and 2.2.2-cryptand (16 $\mathrm{mg}, 0.043 \mathrm{mmol}$ ) were dissolved in $1: 1 \mathrm{THF} / \mathrm{C}_{6} \mathrm{H}_{6}(2 \mathrm{~mL})$ to form a pink solution, which was combined with $\mathrm{KC}_{8}(18 \mathrm{mg}, 0.13 \mathrm{mmol})$ to produce red crystals suitable for X-ray diffraction $(22 \mathrm{mg})$. The crystals were characterized as a cocrystallized mixture of $[\mathrm{K}(\mathrm{crypt})]\left[\left({ }^{\mathrm{Ad}, \mathrm{Me}} \mathrm{ArO}\right)_{3^{-}}\right.$ mes)Er], 2-Er, and [K(crypt)][(( $\left.\left.\left.{ }^{\mathrm{Ad}, \mathrm{Me}} \mathrm{ArO}\right){ }_{3} \mathrm{mes}\right) \mathrm{ErH}\right]$, 3-Er, of an approximate $55: 45$ ratio. UV-vis (THF) $\lambda_{\max } \mathrm{nm}\left(\varepsilon, \mathrm{M}^{-1} \mathrm{~cm}^{-1}\right)$ : 305 (21 000), 330 (4800 shoulder), 430 (5600), 500 (2500 shoulder), 600 (300).

\section{$\left.[\mathrm{K}(\mathrm{crypt})]\left[\left({ }^{\mathrm{Ad}, \mathrm{Me}} \mathrm{ArO}\right)_{3} \mathrm{mes}\right) \mathrm{Dy}\right]$ and [K(crypt $\left.)\right]\left[\left(\left(^{\mathrm{Ad}, \mathrm{Me}} \mathrm{ArO}\right)_{3} \mathrm{mes}\right)\right.$ DyH], 2-Dy/3-Dy}

$\left[\left(\left({ }^{\mathrm{Ad}, \mathrm{Me}} \mathrm{ArO}\right)_{3} \mathrm{mes}\right) \mathrm{Dy}\right]$, 1-Dy, $(20 \mathrm{mg}, 0.019 \mathrm{mmol})$ and 2.2.2cryptand (7 mg, $0.02 \mathrm{mmol}$ ) were dissolved in THF (1 mL) to form a colorless solution. The solution was transferred to scintillation vial with a potassium smear (excess) and stored overnight at $-35^{\circ} \mathrm{C}$. The resultant dark red solution was layered with $\mathrm{Et}_{2} \mathrm{O}(8 \mathrm{~mL})$ and stored at $-35{ }^{\circ} \mathrm{C}$ for $36 \mathrm{~h}$ to produce dark red crystals suitable for X-ray diffraction $(10 \mathrm{mg})$. The crystals were characterized as a cocrystallized mixture of [K(crypt)] $\left[\left(\left({ }^{\mathrm{Ad}, \mathrm{Me}} \mathrm{ArO}\right)_{3} \mathrm{mes}\right) \mathrm{Dy}\right], \quad$ 2-Dy, and $[\mathrm{K}(\mathrm{crypt})]\left[\left(\left({ }^{\mathrm{Ad}, \mathrm{Me}} \mathrm{ArO}\right)_{3} \mathrm{mes}\right)\right.$ $\mathrm{DyH}$ ], 3-Dy, of an approximate $63: 37$ ratio. 
$[\mathrm{K}(\mathrm{crypt})]\left[\left(\left({ }^{\mathrm{Ad}, \mathrm{Me}} \mathrm{ArO}\right)_{3} \mathrm{mes}\right) \mathrm{Dy}\right]$ and [K(crypt $\left.)\right]\left[\left(\left({ }^{\mathrm{Ad}, \mathrm{Me}} \mathrm{ArO}\right)_{3} \mathrm{mes}\right)\right.$ Dy $(\mathrm{OH})], 2-D y / 4-D y$

As described for 2-Nd, [( $\left.\left.\left({ }^{\mathrm{Ad}, \mathrm{Me}} \mathrm{ArO}\right)_{3} \mathrm{mes}\right) \mathrm{Dy}\right], \mathbf{1 - D y},(90 \mathrm{mg}, 0.086$ $\mathrm{mmol}$ ) and 2.2.2-cryptand ( $32 \mathrm{mg}, 0.085 \mathrm{mmol}$ ) were dissolved in $3: 1 \mathrm{THF} / \mathrm{C}_{6} \mathrm{H}_{6}(3 \mathrm{~mL})$ to form an off-white solution, which was combined with $\mathrm{KC}_{8}(18 \mathrm{mg}, 0.13 \mathrm{mmol})$ to produce red crystals suitable for X-ray diffraction. The crystals were characterized as a co-crystallized mixture of $[\mathrm{K}(\mathrm{crypt})]\left[\left({ }^{\mathrm{Ad}, \mathrm{Me}} \mathrm{ArO}\right){ }_{3} \mathrm{mes}\right)$ Dy], 2-Dy, and [K(crypt) $\left.]\left[\left({ }^{\mathrm{Ad}, \mathrm{Me}} \mathrm{ArO}\right)_{3} \mathrm{mes}\right) \operatorname{Dy}(\mathrm{OH})\right]$, 4-Dy, of an approximate $2: 3$ ratio.

\section{$\left[\mathrm{K}(18-\text { crown-6)(THF })_{2}\right]\left[\left(\left(^{\mathrm{Ad}, \mathrm{Me}} \mathrm{ArO}\right)_{3} \mathrm{mes}\right) \mathrm{Dy}\right]$ and [K(18-crown- 6)(THF $\left.\left.)_{2}\right]\left[\mathrm{K}(18-\text { crown-6)(THF })_{2}\right]\left[\left({ }^{\mathrm{Ad}, \mathrm{Me}} \mathrm{ArO}\right)_{3} \mathrm{mes}\right) \mathrm{DyH}\right], 5-\mathrm{Dy} /$ 6-Dy}

[(( $\left.\left.\left.{ }^{\mathrm{Ad}, \mathrm{Me}} \mathrm{ArO}\right)_{3} \mathrm{mes}\right) \mathrm{Dy}\right]$, 1-Dy, $(50 \mathrm{mg}, 0.048 \mathrm{mmol})$ and 18-crown-6 (13 mg, $0.048 \mathrm{mmol}$ ) were dissolved in THF $(1 \mathrm{~mL})$ to give a colorless solution. Excess potassium was added and the solution was stored overnight in the glovebox freezer. The resultant dark red solution was layered with $\mathrm{Et}_{2} \mathrm{O}(4 \mathrm{~mL})$ and stored at $-35{ }^{\circ} \mathrm{C}$ for $48 \mathrm{~h}$ at $-35{ }^{\circ} \mathrm{C}$ to produce red crystals suitable for X-ray diffraction $(29 \mathrm{mg})$. The crystals were characterized as a co-crystallized mixture of $\left[\mathrm{K}(18 \text {-crown-6)(THF })_{2}\right]$ $\left[\left(\left({ }^{\mathrm{Ad}, \mathrm{Me}} \mathrm{ArO}\right)_{3} \mathrm{mes}\right) \mathrm{Dy}\right], \quad$ 5-Dy, and [K(18-crown-6)(THF $\left.)_{2}\right]$ $\left[\left(\left({ }^{\mathrm{Ad}, \mathrm{Me}} \mathrm{ArO}\right)_{3} \mathrm{mes}\right) \mathrm{DyH}\right], 6-\mathrm{Dy}$, of an approximate $1: 1$ ratio with two THF molecules in the lattice. UV-vis (THF) $\lambda_{\max } \mathrm{nm}$ $\left(\varepsilon, \mathrm{M}^{-1} \mathrm{~cm}^{-1}\right)$ : 300 (18 000), 330 (3500 shoulder), 430 (4900), 480 (2600 shoulder), 550 (600 shoulder). Anal. calcd for $\mathrm{C}_{91} \mathrm{H}_{131.5}$ DyKO $_{13}$ : C, 67.84; H, 8.20. Found: C, 65.15; H, 7.61. Additional elemental analyses experiments gave low carbon and hydrogen values. The found $\mathrm{CH}$ ratios of $\mathrm{C}_{91} \mathrm{H}_{131}, \mathrm{C}_{91} \mathrm{H}_{129.7}$ are consistent with the formula and suggest incomplete combustion.

\section{$\mathrm{X}$-ray data collection, structure determination, and} refinement

Crystallographic details for compounds 1-Ln $(\mathrm{Ln}=\mathrm{Nd}, \mathrm{Gd}$, Dy, and Er), 2-Nd, 2-Ln/3-Ln (Ln = Gd, Dy, Er), 2-Dy/4-Dy, and 5-Dy/ 6-Dy are summarized in the ESI. $\dagger$

\section{Conflicts of interest}

The authors declare no competing financial interest.

\section{Acknowledgements}

We thank the U.S. National Science Foundation for support of the experimental studies (CHE-1565776 to W. J. E.) and the theoretical studies (CHE-1464828 to F. F.). We also thank Professor Arnold L. Rheingold, Dr Milan Gembicky, Dr Jason R. Jones, and Dr Jordan F. Corbey for assistance with X-ray crystallography along with Professor A. S. Borovik and Victoria F. Oswald for spectroscopic assistance. We also thank the NSF for providing graduate fellowship support for C. T. P. (DGE1321846). D. P. H acknowledges the Graduate School Molecular Science (GSMS) of FAU Erlangen-Nürnberg for generous support. The Bundesministerium für Bildung und Forschung
(BMBF, support codes 02NUK012C and 02NUK020C), the FAU Erlangen-Nürnberg, and COST Action CM1006 are acknowledged for funding (to K. M.).

\section{References}

1 P. B. Hitchcock, M. F. Lappert, L. Maron and A. V. Protchenko, Angew. Chem., Int. Ed., 2008, 47, 1488-1491.

2 M. R. MacDonald, J. W. Ziller and W. J. Evans, J. Am. Chem. Soc., 2011, 133, 15914-15917.

3 M. R. MacDonald, J. E. Bates, M. E. Fieser, J. W. Ziller, F. Furche and W. J. Evans, J. Am. Chem. Soc., 2012, 134, 8420-8423.

4 M. R. MacDonald, J. E. Bates, J. W. Ziller, F. Furche and W. J. Evans, J. Am. Chem. Soc., 2013, 135, 9857-9868.

5 M. E. Fieser, M. R. MacDonald, B. T. Krull, J. E. Bates, J. W. Ziller, F. Furche and W. J. Evans, J. Am. Chem. Soc., 2015, 137, 369-382.

6 M. R. MacDonald, M. E. Fieser, J. E. Bates, J. W. Ziller, F. Furche and W. J. Evans, J. Am. Chem. Soc., 2013, 135, 13310-13313.

7 C. J. Windorff, M. R. MacDonald, M. R. Meihaus, J. W. Ziller, J. R. Long and W. J. Evans, Chem.-Eur. J., 2016, 22, 772-782.

8 C. J. Windorff, G. P. Chen, J. N. Cross, W. J. Evans, F. Furche, A. J. Gaunt, M. T. Janicke, S. A. Kozimor and B. L. Scott, J. Am. Chem. Soc., 2017, 139, 3970-3973.

9 D. H. Woen and W. J. Evans, in Handbook on the Physics and Chemistry of the Rare Earths Including Actinides, ed. J. C. G. Bünzli and V. K. Percharsky, Elsevier, Amsterdam, 1st edn, 2016, vol. 50, ch. 293, pp. 337-394.

10 W. J. Evans, Organometallics, 2016, 35, 3088-3100.

11 H. S. La Pierre, H. Kameo, D. P. Halter, F. W. Heinemann and K. Meyer, Angew. Chem., Int. Ed., 2014, 53, 7154-7157.

12 H. S. La Pierre, A. Scheurer, F. W. Heinemann, W. Hieringer and K. Meyer, Angew. Chem., Int. Ed., 2014, 53, 7158-7162.

13 D. C. Bradley, R. C. Mehrotra, I. P. Rothwell and A. Singh, Alkoxo and Aryloxo Derivatives of Metals, Academic Press, London, 2001.

14 R. C. Mehrotra, A. Singh and U. M. Tripathi, Chem. Rev., 1991, 91, 1287-1303.

15 T. J. Boyle and L. A. M. Ottley, Chem. Rev., 2008, 108, 18961917.

16 P. B. Hitchcock, M. F. Lappert and R. G. Smith, Inorg. Chim. Acta, 1987, 139, 183-184.

17 H. A. Stecher, A. Sen and A. L. Rheingold, Inorg. Chem., 1988, 27, 1130-1132.

18 M. F. Lappert, A. Singh and R. G. Smith, Inorg. Synth., 1990, 27, 164-168.

19 T. J. Boyle, S. D. Bunge, P. G. Clem, J. Richardson, J. T. Dawley, L. A. M. Ottley, M. A. Rodriguez, B. A. Tuttle, G. Avilucea and R. G. Tissot, Inorg. Chem., 2005, 44, 15881600.

20 J. R. van den Hende, P. B. Hitchcock, S. A. Holmes and M. F. Lappert, J. Chem. Soc., Dalton Trans., 1995, 1435-1459.

21 D. M. Barnhart, D. L. Clark, J. C. Gordon, J. C. Huffman, R. L. Vincent, J. G. Watkin and B. D. Zwick, Inorg. Chem., 1994, 33, 3487-3497. 
22 T. J. Boyle, L. A. M. Ottley, L. N. Brewer, J. Sigman, P. G. Clem and J. J. Richardson, Eur. J. Inorg. Chem., 2007, 3805-3815.

23 (a) R. J. Butcher, D. L. Clark, S. K. Grumbine, R. L. VincentHollis, B. L. Scott and J. G. Watkin, Inorg. Chem., 1995, 34, 5468-5476; (b) G. B. Deacon, P. E. Fanwick, A. Gitlits, I. P. Rothwell, B. W. Skelton and A. H. White, Eur. J. Inorg. Chem., 2001, 1505-1514.

24 G. B. Deacon, T. Feng, C. M. Forsyth, A. Gitlits, D. C. R. Hockless, Q. Shen, B. W. Skelton and A. H. White, J. Chem. Soc., Dalton Trans., 2000, 961-966.

25 G. B. Deacon, T. Feng, B. W. Skelton and A. H. White, Aust. J. Chem., 1995, 48, 741-756.

26 G. B. Deacon, S. Nickel, P. MacKinnon and E. R. T. Tiekink, Aust. J. Chem., 1990, 43, 1245-1257.

27 (a) G. B. Deacon, C. M. Forsyth, P. C. Junk, B. W. Skelton and A. H. White, Chem.-Eur. J., 1999, 5, 1452-1459; (b) G. B. Deacon, P. C. Junk and G. J. Moxey, Chem.-Asian J., 2009, 4, 1309-1317.

28 G. B. Deacon, T. Feng, P. C. Junk, B. W. Sketon and A. H. White, Dalton Trans., 1997, 1181-1186.

29 G. B. Deacon, G. D. Fallon, C. M. Forsyth, S. C. Harris, P. C. Junk, B. W. Skelton and A. H. White, Dalton Trans., 2006, 802-812.

30 G. B. Deacon, A. Gitlits, P. C. Junk, B. W. Skelton and A. H. White, Z. Anorg. Allg. Chem., 2005, 631, 861-865.

31 G. B. Deacon, P. C. Junk, G. J. Moxey, K. Ruhlandt-Senge, C. S. Prix and M. F. Zuniga, Chem.-Eur. J., 2009, 15, 55035519.

32 G. B. Deacon, P. C. Junk and G. J. Moxey, Chem.-Asian J., 2009, 4, 1717-1728.

33 D. L. Clark, J. G. Watkin and J. C. Huffman, Inorg. Chem., 1992, 31, 1556-1558.

34 L.-W. Yang, S. Liu, E. Wong, S. J. Rettig and C. Orvig, Inorg. Chem., 1995, 34, 2164-2178.

35 H.-D. Amberger, H. Reddmann, C. Guttenberger, B. Unrecht, L. Zhang, C. Apostolidis, O. Walter and B. Z. Kanellakopulos, Z. Anorg. Allg. Chem., 2003, 629, 1522-1534.

36 H. Skår, A. Bienfait, M. Schnitzlbaumer, K. W. Törnroos and R. Anwander, Z. Anorg. Allg. Chem., 2014, 640, 604-615.

37 L. A. M. Steele, T. J. Boyle, R. A. Kemp and C. Moore, Polyhedron, 2012, 42, 258-264.

38 S. Hamidi, G. B. Deacon, P. C. Junk and P. Neumann, Dalton Trans., 2012, 41, 3541-3552.

39 F. A. Cotton and W. Schwotzer, J. Am. Chem. Soc., 1986, 108, 4657-4658.

40 F. A. Cotton and W. Schwotzer, Organometallics, 1987, 6, 1275-1280.
41 B. Fan, Q. Shen and Y. Lin, J. Organomet. Chem., 1989, 376, 61-66.

42 B. Fan, Q. Shen and Y. Lin, J. Organomet. Chem., 1989, 377, 51-58.

43 A. A. Fagina, M. N. Bochkarev, S. A. Kozimor, J. W. Ziller and W. J. Evans, Z. Anorg. Allg. Chem., 2005, 631, 2848-2853.

44 H. Liang, Q. Shen, G. Jingwen and Y. Lin, J. Organomet. Chem., 1994, 474, 113-116.

45 S. Liu, J. W. Ziller, Y. Q. Zhang, B. W. Wang, W. J. Evans and S. Gao, Chem. Commun., 2014, 50, 11418-11420.

46 Q. Liu, Y. H. Lin and Q. Shen, Acta Crystallogr., Sect. C: Cryst. Struct. Commun., 1997, 53, 1579-1580.

47 A. S. Filatov, S. N. Gifford, D. K. Kumara and M. A. Petrukhina, Acta Crystallogr., Sect. E: Struct. Rep. Online, 2009, 65, m286-m287.

48 A. S. Filatov, A. Y. Rogachev and M. A. Petrukhina, J. Mol. Struct., 2008, 890, 116-122.

49 H. Liang, Q. Shen, S. Jin and Y. Lin, J. Chem. Soc., Chem. Commun., 1992, 480-481.

50 Y.-M. Yao, Y. Zhang, Q. Shen, Q.-C. Liu, Q.-J. Meng and Y.-H. Lin, Chin. J. Chem., 2001, 19, 588-592.

51 R. D. Shannon, Acta Crystallogr., Sect. A: Cryst. Phys., Diffr., Theor. Gen. Crystallogr., 1976, 32, 751-767.

52 T. S. Piper and G. Wilkinson, J. Inorg. Nucl. Chem., 1956, 3, 104-124.

53 J. F. Corbey, D. H. Woen, C. T. Palumbo, M. E. Fieser, J. W. Ziller, F. Furche and W. J. Evans, Organometallics, 2015, 34, 3909-3921.

54 L. R. Morss, Chem. Rev., 1976, 76, 827-841.

55 F. Jaroschik, A. Momin, F. Nief, X.-F. Le Goff, G. B. Deacon and P. C. Junk, Angew. Chem., Int. Ed., 2009, 48, 1117-1121.

56 H. M. Crosswhite, H. Crosswhite, W. T. Carnall and A. P. Paszek, J. Chem. Phys., 1980, 72, 5103-5117.

57 J. Tao, J. P. Perdew, V. N. Staroverov and G. E. Scuseria, Phys. Rev. Lett., 2003, 91, 146401.

58 F. Weigend and R. Ahlrichs, Phys. Chem. Chem. Phys., 2005, 7, 3297-3305.

59 A. Schafer, H. Horn and R. Ahlrichs, J. Chem. Phys., 1992, 97, 2571-2577.

60 F. T. Edelmann and P. Poremba, in Synthetic Methods of Organometallic and Inorganic Chemistry, ed. W. A. Hermann, Georg Thieme Verlag Stuttgart, New York, 1997, vol. 6 , ch. 3, pp. 38-40.

61 D. E. Bergbreiter and J. M. Killough, J. Am. Chem. Soc., 1978, 100, 2126-2134. 